\title{
Thymosin Apha 1 - A Peptide Immune Modulator with a Broad Range of Clinical Applications
}

\section{Cynthia W. Tuthill ${ }^{*}$ and Robert S. King}

SciClone Pharmaceuticals Inc., 950 Tower Lane, Suite 900, Foster City, California, USA

\begin{abstract}
Thymosin alpha 1 (thymalfasin, Ta1), the active ingredient in ZADAXIN ${ }^{\circledR}$, is a peptidic biological response modifier which activates various cells of the immune system. Ta1 is therefore expected to have clinical benefits in disorders where immune responses are impaired or ineffective, such as acute and chronic infections, cancers, and vaccine non-responsiveness, all of which are hallmarks of an impaired or inadequate immune response. Importantly, Ta1 acts without overstimulation of cytokine production and is generally well tolerated; it has an excellent safety profile and does not appear to induce the side effects and toxicities commonly associated with agents in this class such as interferonalpha and interleukin-2.

Ta1 has been shown to act through Toll-like receptors, linking to intracellular cell-signaling pathways and leading to stimulation of the immune system, including T helper cells, cytotoxic T cells, and natural killer cells.

Clinical studies with Ta1 have been conducted and shown evidence of benefit in subjects with acute or chronic viral or bacterial infections, including subjects with severe sepsis, infections after bone marrow transplant, chronic hepatitis $\mathrm{B}$ or $\mathrm{C}$, or acquired immune deficiency syndrome. Ta1 has also shown promise in clinical evaluation as an adjunctive treatment in subjects suffering from various types of cancer, including hepatocellular carcinoma, non-small-cell lung cancer, melanoma, renal, breast and gastric cancers; and in subjects receiving vaccines (geriatric subjects receiving influenza vaccine and subjects with renal failure receiving influenza or hepatitis vaccine).
\end{abstract}

Keywords: Thymosin alpha 1; ZADAXIN; Immune modulation; Sepsis; Hepatitis; Cancer; Vaccination

\section{Introduction}

The peptide thymosin alpha 1 (thymalfasin, Ta1; commercial name ZADAXIN $^{\oplus}$ ) is a peptide of 28 amino acids (Figure 1) which was originally isolated from thymic tissue as one of the compounds responsible for reconstitution of immune function in thymecotmized animal models $[1,2]$.

Endogenous Ta1 can be detected in serum, where levels measured in healthy adults by immunoassays are in the 0.1 to $1.0 \mathrm{ng} / \mathrm{mL}$ range $[3,4]$. The circulating concentration of Ta1 tends to be lower in diseased individuals and higher during pregnancy [5-8]. Ta1, found in highest concentrations in the thymus, has also been found in spleen, lung, kidney, brain, blood, and a number of other tissues.

Ta1 is a biological response modifier which activates various cells of the immune system, and is a therefore expected to have clinical benefits in disorders where immune responses are impaired or ineffective. These disorders include acute and chronic infections (including severe sepsis, infections after bone marrow transplant, lung infections including Chronic Obstructive Pulmonary Disorder (COPD), hepatitis $\mathrm{B}$ and $\mathrm{C}$, and HIV), cancers (HCC, lung cancer, and melanoma), and vaccine non-responsiveness, all of which are hallmarks of an impaired or inadequate immune response. Although originally isolated from bovine tissue, the identical synthetic peptide has been evaluated in clinical studies and gained marketing approval in several countries, most notably in China.

\section{Mechanism of Action}

Investigation of the mechanism of action of Ta1 at the cellular level has shown both immune modulating and direct-acting effects (Figure 2). Ta1 interacts with intracellular Toll-Like Receptors (TLR; a family of proteins that mediate innate immunity) and may gain access to the cell by crossing the membrane unassisted, as it can fold into a structured helix in organic solvents $[9,10]$.

\section{Immune stimulating effects}

Ta1's interaction with TLR9 and TLR2 on Dendritic Cells (DCs) and precursor $\mathrm{T}$ cells leads to a stimulation of intracellular cell-signaling pathways, including NFkappaB and p38 MAPK [10-12], and results in:

- Increased Natural Killer (NK) activity [13-25]

- A shift of T helper (Th or CD4) cells to the Th1 cell subset [11,26-28]

- Increased expression of Th1 type cytokines such as Interleukin (IL) 2 [24,29,30,31], and Interferon (IFN)-alpha [24,29-34]

- Increased levels of Cytotoxic $\mathrm{T}$ ( Tc1 or CD8) cells $[15,16,22,23,25,35,36]$

Ac-Ser-Asp-Ala-Ala-Val-Asp-Thr-Ser-Ser-Glu-Ile-Thr-Thr

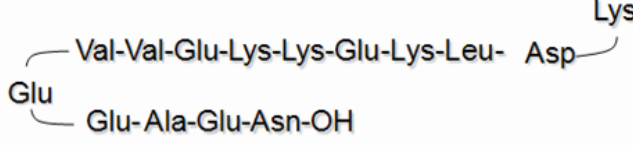

Figure 1: Primary structure of Ta1. Thymosin alpha 1 (Ta1) is a synthetic 28 amino acid peptide, acetylated at the $\mathrm{N}$ terminus.

*Corresponding author: Cynthia W. Tuthill, PhD, SciClone Pharmaceuticals Inc., 950 Tower Lane, Suite 900, Foster City, CA 94404, USA, E-mail: CTuthill@SCICLONE.com

Received June 27, 2013; Accepted September 24, 2013; Published October 01, 2013

Citation: Tuthill CW, King RS (2013) Thymosin Apha 1 - A Peptide Immune Modulator with a Broad Range of Clinical Applications. Clin Exp Pharmacol 3: 133. doi:10.4172/2161-1459.1000133

Copyright: (c) 2013 Tuthill CW, et al. This is an open-access article distributed under the terms of the Creative Commons Attribution License, which permits unrestricted use, distribution, and reproduction in any medium, provided the original author and source are credited. 
Citation: Tuthill CW, King RS (2013) Thymosin Apha 1 - A Peptide Immune Modulator with a Broad Range of Clinical Applications. Clin Exp Pharmacol 3: 133. doi:10.4172/2161-1459.1000133

Page 2 of 17

- Increased activation of DCs [36-40]

These immunological effects can explain Tal's effectiveness in indications where a stimulated or enhanced immune response is desirable for health outcome, including viral, bacterial, and fungal infections and cancers, as well as vaccination of immunocompromised subjects (e.g., the elderly or those with renal failure). NK cells, and CD4 helper Th1 and CD8 cytotoxic Tc1 cells acting in concert, lead to killing of virally-infected cells and tumors [41-43]. Activated DCs also provide anti-viral and anti-tumor responses [44-49], as well as killing of bacterial and fungal infections. Activated DCs also lead to more efficient antigen presentation [50] for increased production of antibodies, an effect of Ta1 [51-53] which is especially important for the elderly who do not respond well to vaccination due to being immunosuppressed.

Ta1 also increases lymphocytic infiltration to sites of disease [15], and a correlation between tumor-infiltrating lymphocytes and prognosis for patients with stage IV cancer has been documented [54]. Moreover, Tal can reduce apoptosis of immune cells, as shown in mouse $[55,56]$ and human $[57,58]$ thymocytes, and increase stem cell expansion in immunosuppressed mice [59-61]. Additionally, Ta1 leads to increased expression of the thymopoetic cytokines IFN-alpha, IL-7, and IL-15 [37,57].

\section{Immune dampening effects}

Importantly, it has also been shown that Ta1 stimulates activity of Indoleamine-2,3-Dioxygenase (IDO) in plasmacytoid DCs $[37,40,62]$. Stimulation of IDO leads to an increase in FoxP3 IL-10 producing regulatory $\mathrm{T}$ cells, and this increase leads to feedback inhibition of cytokine production, hence dampening immune response to prevent a pro-inflammatory cytokine storm and possibly autoimmune phenomena (Figure 3).

\section{Direct-acting effects}

Ta1 has also been shown to increase expression of proteins on the surface of virally-infected or tumor cells, including those that mediate antigen presentation such as Major Histocompatibility (MHC) Class I, MHC Class II, and beta-2 microglobulin [36,63], as well as tumorspecific antigens $[64,65]$. Immune escape by virally-infected and tumor cells has been correlated with down-regulation of antigen-presenting molecules $[66,67]$.

Ta1 treatment also increases intracellular Glutathione (GSH) [68], important for anti-viral effects, and importantly has been shown to directly inhibit the in vitro growth of virally infected and cancer cells $[69,70]$.

A number of previous review articles [71-80] address the history, biological effects, and potential therapeutic indications for Ta1.

\section{Tal Studies in Infectious Disease}

Ta1 has been evaluated for prevention and treatment of many different acute and chronic infectious diseases, including bacterial, fungal, and viral infections, as outlined in the studies described below.

\section{Sepsis}

In the US, severe sepsis is still one of the leading causes of death and accounts for an estimated 750,000 new cases every year and

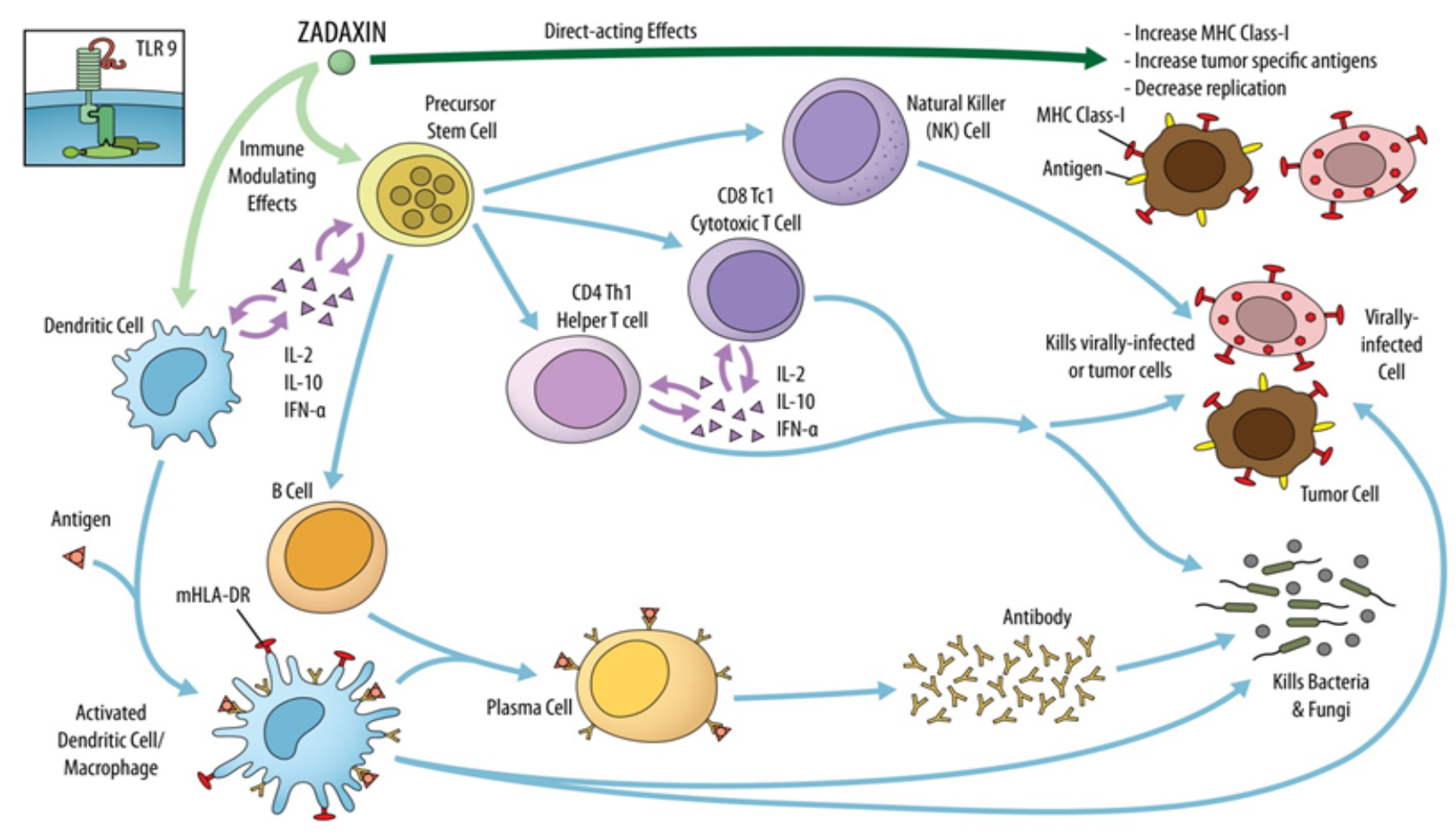

Abbreviations: IL = interleukin; IFN = interferon; $\mathrm{MHC}=$ major histocompatibility antigen; $\mathrm{mHLA}=$ monocyte human lymphocyte antigen; NK $=$ natural killer; Tc1 = cytotoxic Th1-like cell subset of T cells; Th1 = T helper 1 subset of T cells; TLR = toll-like receptor; ZADAXIN = thymosin alpha 1

Figure 2: Immune stimulating mechanism of action of Ta1. Thymosin alpha 1 (ZADAXIN) has a dual mechanism of action, with immune modulating effects that help fight infections and cancer, as well as direct-acting effects on infected or tumor cells themselves. 
Citation: Tuthill CW, King RS (2013) Thymosin Apha 1 - A Peptide Immune Modulator with a Broad Range of Clinical Applications. Clin Exp Pharmacol 3: 133. doi:10.4172/2161-1459.1000133

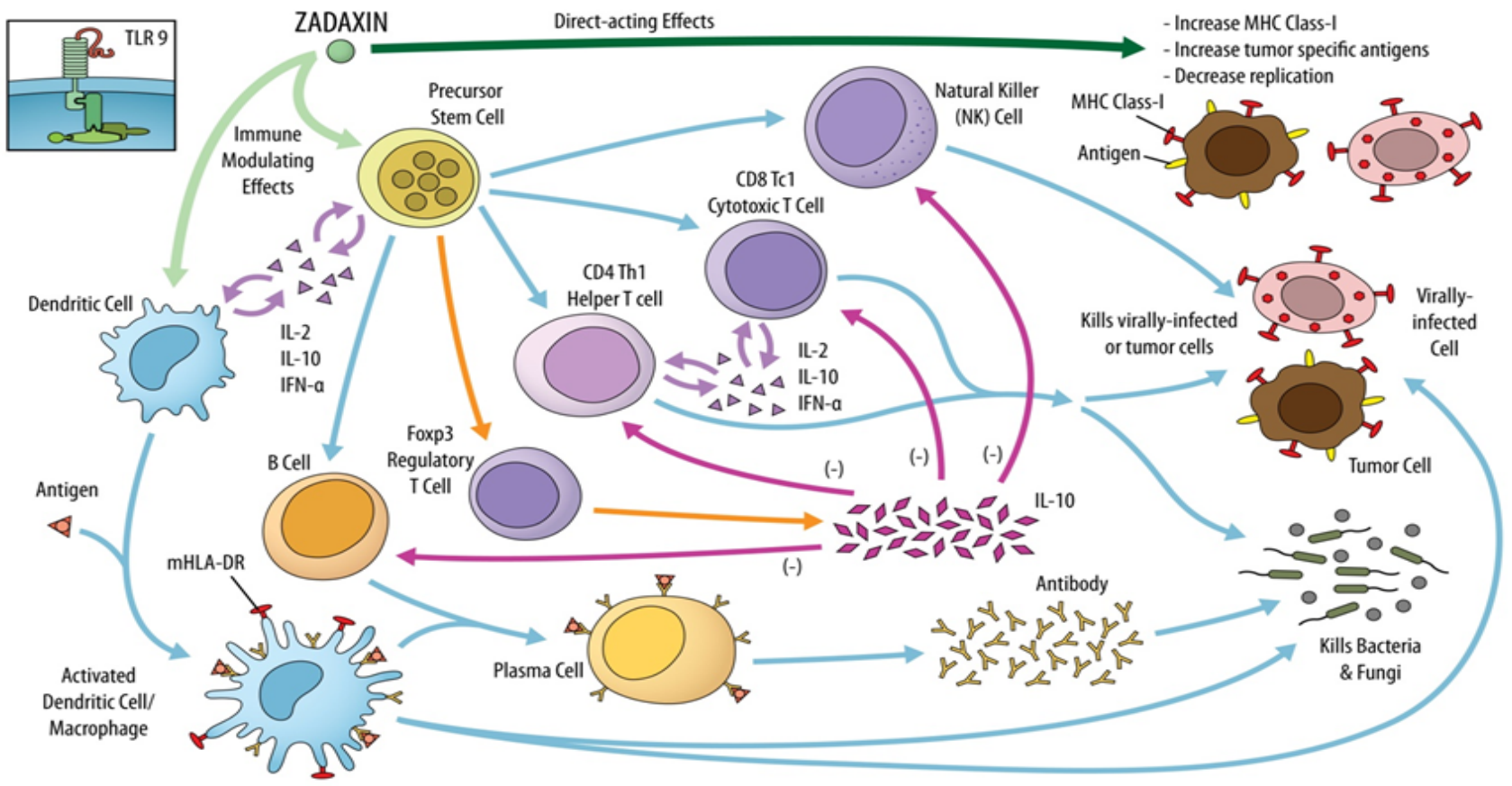

Abbreviations: IL = interleukin; IFN = interferon; $\mathrm{MHC}=$ major histocompatibility antigen; $\mathrm{mHLA}=$ monocyte human lymphocyte antigen; NK = natural killer; Tc1 = cytotoxic Th1-like cell subset of T cells; Th1 = T helper 1 subset of T cells; TLR = toll-like receptor; ZADAXIN = thymosin alpha 1

Figure 3: Immune dampening mechanism of action of Ta1. Thymosin alpha 1 (ZADAXIN) has a feed-back dampening effect on the immune system, leading to increases in regulatory $T$ cells and a decrease in the production of inflammatory cytokines.

about $10 \%$ of admissions to intensive care units [81]. The mortality rates for patients with sepsis, severe sepsis and septic shock has been approximately reported to be 16,20 and $46 \%$, respectively. A large number of experimen $\neg$ tal agents including numerous antiinflammatory and immuno $\neg$ modulatory drugs have been tried, but few, if any, have yet been found to significantly reduce the risk of death as single agents. Although bacteria play a significant role in the onset of sepsis, in many cases the primary cause of death is due to the paralysis and dysregulation of the immune system and the severe proinflammatory response due to a cascade of inflammatory cytokines and chemokines that are multi-organ in nature.

In severe sepsis, sepsis-induced immunosuppression is increasingly recognized as the overriding immune dysfunction in these vulnerable patients [82] and there is now agreement that many patients with severe sepsis survive the first critical hours of the syndrome but eventually die later in a state of immunosuppression that is illustrated by the patients' difficulty to fight the primary bacterial infection, decreased resistance to secondary nosocomial infections, and reactivation of viral infections [83]. Consequently, an immunostimulatory therapy such as Tal could be used to restore immune functions in the most immunodepressed patients.

The use of Ta1 in treatment of 361 subjects diagnosed with severe sepsis was recently evaluated in a large, prospective, multi-center, single-blind, randomized, and controlled trial in China [84] which was conducted in the Intensive Care Units (ICUs) of six tertiary, teaching hospitals. The trial was registered with ClinicalTrials.gov, number NCT00711620.

Within 28 days after enrollment, 47 of 181 patients in the Ta1 treatment group (26.0\%) and 63 of 180 patients in the control group
(35.0\%) expired. The relative risk of death in the Tal group as compared to the control group was 0.74 (95\% Confidence Interval [CI] 0.54 to 1.02 ) with a $p$ value of 0.062 in the nonstratified analysis. There was a 9.0\% (95\% CI -0.5 to $18.5 \%$ ) absolute reduction in mortality in the Ta1 group. Patients in the Ta1 group survived longer after enrollment than the control group (log rank, $p=0.049$; Figure 4$)$. Greater improvements in Monocyte Human Lymphocyte Antigen (mHLA)-DR were observed in patients in the Tal group on day 3 (mean difference in mHLADR changes between the two groups was $3.9 \%, 95 \%$ CI 0.2 to $7.6 \%$, $p=0.037)$ and day $7(p=0.017)$. No serious drug-related adverse events were recorded.

In addition to the trial described above, Ta1 has been used in many studies in combination with standard of care, and also in combination with trypsin Protease Inhibitors (PI) in addition to standard of care, for treatment of severe sepsis. Studies and their results are summarized in Table 1 .

\section{Infections after bone marrow transplant}

While bone marrow transplant offers benefit for treatment of hematological malignancies, next to relapse the main cause of death in these subjects is a $35-40 \%$ Transplant-Related Mortality (TRM) which is largely due to infections (primarily cytomegalovirus and Aspergillus) [94].

As animal models have shown efficacy for Tal in prevention and treatment of Aspergillus infections after bone marrow transplant $[11,38]$, a phase 2 clinical study was conducted in Italy to evaluate the use of Tal after HLA matched or haploidentical stem cell transplant in 75 subjects (Perruccio 2010 and Romani 2012) [95,96]. This study found very promising results: 
Citation: Tuthill CW, King RS (2013) Thymosin Apha 1 - A Peptide Immune Modulator with a Broad Range of Clinical Applications. Clin Exp Pharmacol 3: 133. doi:10.4172/2161-1459.1000133

Page 4 of 17

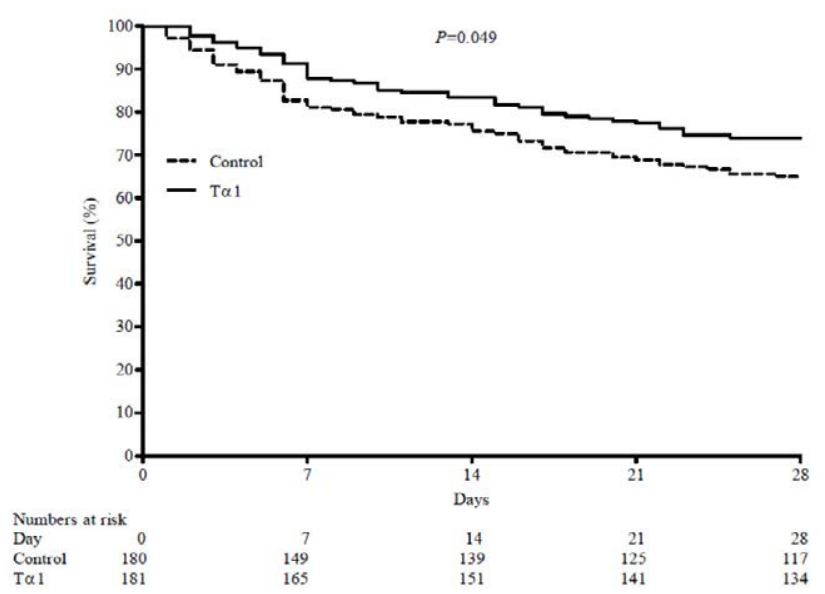

Abbreviations: $\mathrm{Ta} 1=$ thymosin alpha 1

Figure 4: Ta1 improves survival in severe sepsis. Kaplan-Meier estimate of the probability of 28-day survival, in clinical trial comparing the addition of Ta1 to placebo in treatment of severe sepsis [84]

- The cumulative incidence of TRM (mostly infection-related) was $32 \%$ in control subjects but only $7 \%$ in subjects treated with Ta1 $(p=0.02)$

- Event-free survival was increased in Ta1 subjects (40\% versus $20 \%$ in controls; $p=0.02$ )

- $\quad$ Ta1 treatment was a significant independent factor predicting a lower incidence of TRM $(p=0.04)$, which tended to provide better survival $(p=0.09)$

- Tal administration was associated with increased $\mathrm{T}$ cell counts and earlier appearance of functional pathogen-specific $\mathrm{T}$ cells responses (against Aspergillus, Candida, cytomegalovirus, varicellazoster virus, herpes simplex virus, and Toxoplasma).

\section{Other studies in acute infections}

Chronic Obstructive Pulmonary Disease (COPD; including chronic bronchitis and emphysema) is a lung ailment characterized by persistent blockage of airflow from the lungs. COPD is caused by noxious particles of gas, commonly tobacco smoking, which triggers an abnormal inflammatory response in the lungs. Symptoms consist of shortness of breath and low airflow and are poorly reversible. The World Health Organization (WHO) predicts that COPD will become the third leading cause of death worldwide by the year 2030 (http:// www.who.int/respiratory/copd/en). There is no cure, only management guidelines for medicines which can help dilate major air passages of the lungs.

Several studies have evaluated the use of Ta1 in COPD. In China, $\mathrm{Li}$ reported a study with 108 elderly COPD in-patients who were having acute episodes. The subjects were treated with standard of care and half were randomized to also receive Ta1 [97]. They found that clinical efficacy was increased, hospital stay was shortened, and incidence of double infection was decreased $(p<0.05)$. Immune parameters were also significantly improved, more so than in the control group $(p<0.01)$, and there were no adverse effects seen. Another study in China was conducted in 80 subjects with COPD, half of whom received 10 treatments of Ta1 before being followed for 6 months [98]. They found the number of patients with an acute exacerbation of symptoms when evaluated at 3 months or 6 months post-treatment was significantly lower in the group of subjects treated with Ta1 (from 11 down to 4 at 3 months, and from 15 down to 7 at 6 months; $p<0.05$ ). The duration of the acute exacerbations were shorter in the subjects treated with $\mathrm{Ta} 1$, evaluated both at 3 and 6 months after treatment (from 10.5 days down to 4.5 at 3 months, and 14.5 down to 7.6 days at 6 months; $p<0.05$ ), while immune cell parameters were significantly increased in the Ta1 treatment group $(p<0.05)$.

Acute Respiratory Distress Syndrome (ARDS), a sudden failure of the respiratory system characterized by rapid breathing, difficulty getting enough air into the lungs, and low blood oxygen levels, can

\begin{tabular}{|c|c|c|}
\hline Study ID & $\begin{array}{c}\text { \# Subjects } \\
\text { Enrolled }\end{array}$ & Summary of Findings \\
\hline \multicolumn{3}{|c|}{ Subjects treated with Ta1 } \\
\hline Wu 2013 [84] & 367 & $\begin{array}{l}\text { - 28-day mortality decreased ( } 26 \% \text { vs. } 35 \% \text {; } \\
\text { p }=0.062 \text { or } 0.049) \\
\text { Relative risk of death decreased }(0.74) \\
\text { mHLA-DR increased more }\end{array}$ \\
\hline Chen 2007 [85] & 42 & $\begin{array}{l}\text { - 28-day cumulative survival increased ( } 18 / 21 \text { vs. } \\
12 / 21 \text { placebo; } p<0.01) \\
\text { - Shortened length of mechanical ventilation, use } \\
\text { of antibiotics, stay in ICU }\end{array}$ \\
\hline Zhao 2007 [86] & 42 & $\begin{array}{l}\text { - Improvement in lymphocytes, mHLA-DR, IL-10 } \\
(p<0.05) \\
\text { - Decrease in inflammation marker IL-6 }\end{array}$ \\
\hline Li 2009a [87] & 91 & $\begin{array}{l}\text { - Improvement in Marshall and APACHE II } \\
\text { scores and immune parameters } \\
\text { - Shortened length of mechanical ventilation and } \\
\text { stay in ICU }\end{array}$ \\
\hline Wang 2010 [88] & 24 & $\begin{array}{l}\text { - Subjects had severe acute pancreatitis } \\
\text { - Decreased } 28 \text {-day infection rate }(p=0.012) \\
\text { - Decreased sepsis }(p=0.036) \\
\text { - Shorter duration of ICU stay }(p=0.014) \\
\text { - Decreased rate of surgery }(p=0.036)\end{array}$ \\
\hline \multicolumn{3}{|c|}{ Subjects treated with Ta1 plus PI } \\
\hline Lin 2007 [89] & 342 & $\begin{array}{l}\text { 28-day mortality decreased ( } 25.1 \text { vs. } 38.3 \text {; } \\
p=0.0088) \\
\text { 90-day mortality decreased ( } 37.1 \text { vs. } 52.1 \\
p=0.0054) \\
\text { - APACHE II decreased }(p=0.0382) \\
\text { - mHLA-DR increased }\end{array}$ \\
\hline Zhang 2008[90] & 120 & $\begin{array}{l}\text { 28-day survival increased ( } 51.7 \text { vs. } 33.9 \\
p=0.086) \\
\text { - APACHE II improved }(p<0.001) \\
\text { - Shortened length of mechanical ventilation, use } \\
\text { of dopamine, stay in ICU }(p<0.001) \\
\text { - Incidence of shock decreased }(p=0.026)\end{array}$ \\
\hline Li 2009b [91] & 56 & $\begin{array}{l}\text { - 28-day survival increased (78 vs. } 60 \% ; p<0.05 \text { ) } \\
\text { - APACHE II improved }\end{array}$ \\
\hline Chen 2009 [92] & 114 & $\begin{array}{l}\text { 28-day survival increased ( } 54.1 \text { vs. } 35.4 ; \\
p=0.078) \\
\text { - } 60 \text {-day survival increased ( } 54.1 \text { vs. } 28.2 ; \\
p=0.045 \text { ) } \\
\text { - } 90 \text {-day survival increased ( } 47.4 \text { vs. } 20.0 ; \\
\text { p=0.033) } \\
\text { - } \text { APACHE II improved significantly } \\
\text { - Shorter stay in ICU, duration of supportive ven- } \\
\text { tilation, dopamine, and antimicrobial therapy }\end{array}$ \\
\hline Huang 2009[93] & 70 & $\begin{array}{l}\text { 28-day survival increased ( } 63.9 \text { vs. } 41.2 \\
\text { p<0.05) } \\
\text { - Average survival time increased from } 245 \text { to } \\
342 \text { days } \\
\text { - } \text { mHLA-DR increased more }\end{array}$ \\
\hline
\end{tabular}

Abbreviations: APACHE II = Acute Physiology and Chronic Health Evaluation; ICU = intensive care unit; $\mathrm{mHLA}=$ monocyte human leukocyte antigen; $\mathrm{PI}=$ protease inhibitor; $\mathrm{Ta} 1$ = thymosin alpha 1 ; vs. = versus

Table 1: Summary of sepsis studies 
occur in anyone who is critically ill. ARDS has a high mortality rate, up to $40 \%$, although this is significantly improved from the rate of 50 to 70 percent just 20 years ago [99]. In 21 renal transplant subjects in China who had ARDS requiring mechanical ventilation due to severe pneumonia (resulting either from CMV (43\%), bacterial $(33 \%)$, or fungal (5\%) etiology), the benefit of the addition of Ta1 was evaluated [100]. The results showed that 13 of 21 patients $(61.9 \%)$ who received Ta1 survived a significant increase over historical controls. In a followup trial in China, 46 renal transplant patients in which CMV pulmonary infection led to ARDS either received Ta1 (32 subjects) or did not (14 controls). In this study [101] the death rate was significantly reduced in the Ta1 treatment group (21.9\% versus 50\%), the renal transplant success rate was significantly higher ( $78 \%$ versus $50 \%)$, and the number of CD4 and CD8 lymphocytes were significantly increased $(p<0.05)$, suggesting that repairing cellular immunity can reinforce resistance to CMV.

Pseudomonas aeruginosa infections are a major clinical problem in the lungs of immunocompromised and aging populations and account for about $10 \%$ of nosocomial infections (http://textbookofbacteriology. net/themicrobialworld/Pseudomonas.html). A Chinese study evaluated 42 critically ill hospitalized patients with tracheotomies who were treated with Ta1 (1.6 mg daily for 7 days, compared to untreated control; [102]). A significant decrease in lung infection rate was seen in the subjects who received Tal than the control subjects. The Ta1 treated subjects also had significant improvements in white blood cell count, C-reactive protein, TNFa, and IL-6 levels. In a follow up study, a group of 35 older Chinese patients with drug-resistant $P$. aeruginosa pneumonia were treated with Ta1 ( $1.6 \mathrm{mg}$ daily for 5 days, in combination with Sulperazone) and it was found [103] that Ta1 treatment improved clinical symptoms (cure of pneumonia in $71.4 \%$ of subjects compared to $52.4 \%, p<0.05$ ), and the bacterial load was decreased significantly greater than control subjects $(p<0.05)$. Ta1 also led to improved immunological function and reduced inflammation $(p<0.01$ compared to control).

Severe Acute Respiratory Syndrome (SARS) is caused by a novel corona virus that was first identified in Asia in 2003 and quickly spread globally to many countries in Europe, North America and South America before it was contained. After a near pandemic of the virus between November 2003 and July 2003, about 8000 cases were reported with 77 deaths worldwide (http://www.who.int/csr/ sars/country/table2004_04_21/en/endex.html). Treatment of SARS included antipyretics with supportive ventilation and oxygen, since antibiotics were shown to be ineffective. The last reported case of SARS was in 2004. Many persons used Tal prophylactically during that outbreak, and an animal model demonstrated efficacy against the virus. In addition, there were several interesting published reports in China suggesting that Tal treatment may have contributed to controlling development of the disease [104-106] and there were no adverse events reported in over 40 subjects included in these reports.

Ta1 has also shown been used in treatment of a patient infected with the highly pathogenic avian influenza H5N1 strain [107]. After a complex treatment regimen with Ta1, the subject had improvement in $\mathrm{CD} 4 \mathrm{~T}$ cells and appeared to be cured of the influenza infection.

\section{Chronic Hepatitis B (CHB)}

Hepatitis B is an infectious inflammatory disease of the liver caused by the Hepatitis B Virus (HBV). This disease has caused epidemics in many parts of Asia and Africa and is considered an endemic in China. 2 billion people worldwide have been infected by HBV and about
600,000 persons die every year due to consequences of HBV (http:// www.who.int/mediacentre/factsheets/fs204/en/index.html). Typically, most adults will clear an HBV infection without need for medication, but for chronically infected individuals, treatment with anti-virals may be necessary to reduce the risk of cirrhosis or liver cancer. These treatments last from six months to a year, depending on medication and genotype. Chronic HBV is associated with increased risk for developing cirrhosis, liver failure, and hepatocellular carcinoma. Impaired effectiveness of the host cellular immune mechanisms in clearing HBV-infected hepatocytes is thought to explain development of chronic HBV infection.

Interest in using Ta1 for treatment of $\mathrm{CHB}$ was based on the fact that its immunomodulating effects can trigger maturation in lymphocytes, augmentation of T-cell function, and promotion of reconstitution of immune defects. In addition, Ta1 has been shown to be effective in the woodchuck hepatitis model for CHB $[108,109]$. Many clinical studies have investigated the safety and efficacy of Tal for the treatment of $\mathrm{CHB}$, both as monotherapy or in combination treatment with IFNalpha or nucleoside analogs. These studies have shown that Tal can promote disease remission in $26 \%$ to $41 \%$ of the subjects treated and has led to commercial approval for this indication in several countries including China.

Two independent meta-analyses of the hepatitis B Tal monotherapy studies have been conducted. The first one [110] included 435 subjects who had been entered into randomized, controlled studies of Tal monotherapy for CHB (Table 2) [34,111-113]. The analysis demonstrated a statistically significant benefit in favor of Tal therapy inducing a sustained virological response over placebo (Odds Ratio $[\mathrm{OR}]=2.87 ; 95 \%$ CI 1.58-5.22; $p=0.0005$ ). The same meta-analysis also demonstrated a trend in favor of Tal compared with IFN-alpha for sustained virological response $(\mathrm{OR}=2.62 ; 95 \% \mathrm{CI} 0.80-8.56)$

A second meta-analysis was conducted [114] which included 199 subjects [112,115-117]. The ORs [95\% CI] of the virological response, biochemical response and complete response of Tal over IFN-alpha at the end of 6 months treatment were not significant, but were quite impressive at the end of 6 month's follow-up $(3.71$ [2.05, 6.71], 3.12 $[1.74,5.62]$ and $2.69[1.47,4.91]$, respectively). These data showed that compared with IFN-alpha, the benefit of Tal was not immediately significant at the end of therapy, but virological, biochemical and complete responses had a tendency to increase or accumulate gradually after the therapy.

Figure 5 demonstrates typical results seen in these CHB studies. This was a multicenter, randomized, controlled study evaluating Ta1 versus IFN-alpha2b in 33 difficult-to-treat subjects infected with the hepatitis $\mathrm{B}$ precore mutant virus, who are characterized by being HBeAg negative and HBV DNA positive [112]. At the end of the follow up period, Ta1 treatment led to a complete response rate of $41 \%$ $(p<0.05)$, compared to $25 \%$ in the IFN-alpha2b-treated group and only $7 \%$ in untreated subjects.

In addition to the studies included in the meta-analyses, several other clinical trials were conducted $[118,119]$ including an open-labeled, randomized, multicenter, controlled study sponsored investigating the safety and efficacy of Tal in 316 Japanese subjects with CHB [120]. Ta1 monotherapy exhibited equal efficacy when administered at a dose of either $0.8 \mathrm{mg}$ or $1.6 \mathrm{mg}$; the rate of normalization of ALT was $32 \%$ and $37 \%$, respectively ( $p>0.05$ ); clearance of HBV DNA was $26 \%$ and $30 \%(p>0.05)$; clearance of HBeAg was $23 \%$ and $23 \%(\mathrm{p}>0.05)$; and the appearance of anti-HBeAg at 72 weeks was $18 \%$ and $22 \%(p>0.05)$. At 
Citation: Tuthill CW, King RS (2013) Thymosin Apha 1 - A Peptide Immune Modulator with a Broad Range of Clinical Applications. Clin Exp Pharmacol 3: 133. doi:10.4172/2161-1459.1000133

Page 6 of 17

\begin{tabular}{|c|c|c|c|c|c|}
\hline Study Design & Study County & Subjects Enrolled & $\begin{array}{l}\text { Clinical Outcome (at end of } \\
\text { follow up) }\end{array}$ & & \\
\hline Randomized, placebo-controlled double-blind [34] & United States Phase 2 & 20 & Ta1Placebo & $\begin{array}{l}83 \% \\
25 \%\end{array}$ & $\underline{p<0.04}$ \\
\hline $\begin{array}{l}\text { Multicenter, randomized, placebo-controlled double-blind } \\
\text { [111] }\end{array}$ & United StatesPhase 3 & 99 & Ta1Placebo & $\begin{array}{l}24 \% \\
12 \%\end{array}$ & $p<0.11$ \\
\hline Multicenter, randomized, controlled [112] & Italy Phase 3 & 33 & Ta1IFN-alpha2b & $\begin{array}{c}41 \% \\
25 \% \\
7 \%\end{array}$ & $p=0.025$ \\
\hline \multirow{3}{*}{ Multicenter, randomized, controlled open-label [113] } & \multirow{3}{*}{ Taiwan Phase 3} & 158 & Ta1 (6 mo Rx) & $36 \%$ & \\
\hline & & & Ta1 (12 mo Rx) Control & $\begin{array}{l}27 \% \\
25 \%\end{array}$ & \\
\hline & & $98^{1}$ & $\begin{array}{c}\text { Ta1 (6 mo Rx) Ta1 (12 mo Rx) } \\
\text { Control }\end{array}$ & $\begin{array}{c}41 \% \\
38 \% \\
9 \%\end{array}$ & $\begin{array}{c}p<0.004 \\
(6 \text { mo vs. Control) }\end{array}$ \\
\hline Meta-analysis [110] & United States, Taiwan, Italy & 223 & Ta1 (6 mo Rx) Control & $\begin{array}{l}36 \% \\
19 \%\end{array}$ & $p=0.04$ \\
\hline
\end{tabular}

Abbreviations: $\mathrm{CHB}=$ chronic hepatits $\mathrm{B} ; \mathrm{IFN}=$ interferon; Ta1 = thymosin alpha $1 ; \mathrm{vs} .=$ versus

${ }^{1}$ Data from the Chang Gung Memorial Hospital, the major site of the study

Table 2: Meta-analysis of Ta1 CHB monotherapy studies.

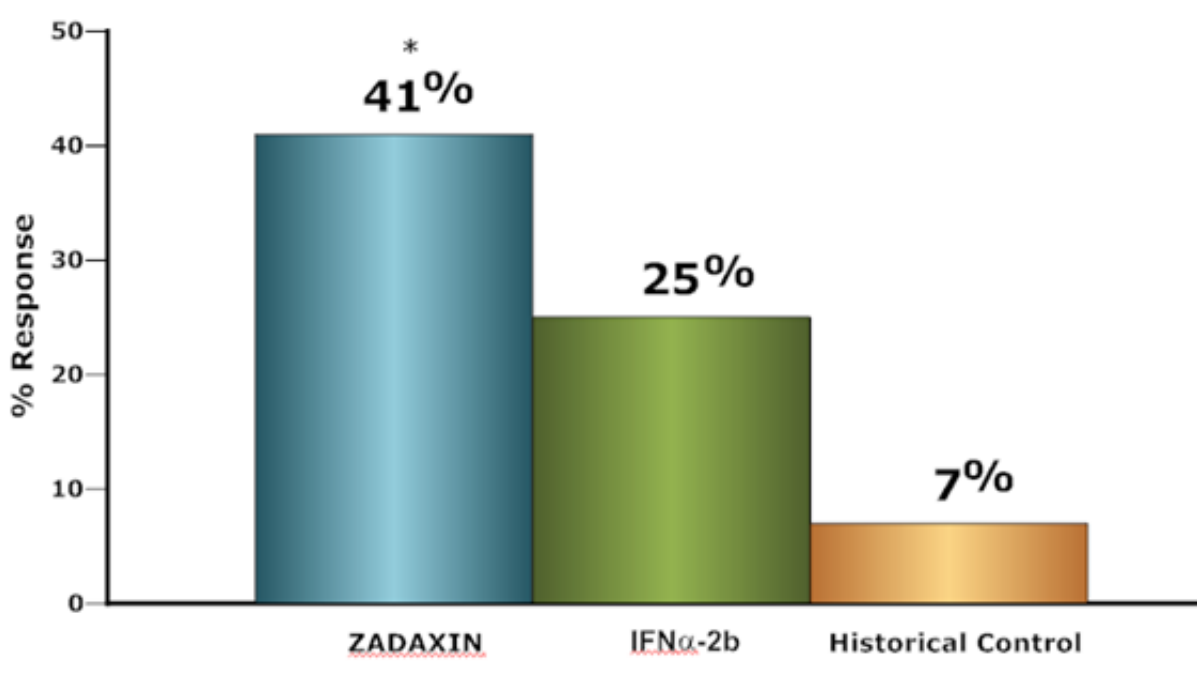

$* P<0.0$ !

Abbreviations: $\mathrm{HBV}=$ hepatitis $\mathrm{B}$ virus; IFN = interferon; ZADAXIN = thymosin alpha 1

Figure 5: Ta1 improves response in difficult-to-treat hepatitis B. A randomized, controlled study comparing the responses of Ta1, IFN-alpha, and untreated historical control subjects with the difficult-to-treat HbeAg-positive hepatitis B infection show improved response (HBV DNA negative) at the end of follow-up, after treatment with Ta1 [112].

72 weeks from baseline, both treatment groups still showed significant improvements in these parameters.

Because of its excellent safety profile, Ta1 may be combined with other therapies to enhance their efficacy without increasing their toxicity. Therefore, clinical trials to improve the effectiveness of other CHB monotherapies by the addition of Ta1 have also been explored. An open label study in Italy tested the combination of low-dose lymphoblastoid IFN-alpha and Ta1 in 15 subjects [121]. Most of the subjects had already failed IFN-alpha2b therapy, and yet Ta1 treatment showed an overall sustained response of $60 \%$ (9/15), including a sustained response in $55 \%(6 / 11)$ of previous IFN-alpha2b treatment failures (compared to the historical retreatment rate of 10\%).

A study in Turkey compared IFN-alpha2b monotherapy with Ta1/ IFN-alpha2b combination therapy in 52 subjects) [122,123]. At the end of 52 weeks, response rates (HBV DNA negative and normal ALT) were $88 \%$ and $70 \%$, respectively, for the Tal combination therapy and IFN-alpha2b alone. At the end of 78 weeks, response rates (HBV DNA negative and normal ALT) were $74 \%$ and $40 \%$ respectively $(p=0.002$ ). The Ta1 treatment group retained this response 18 months after completion of therapy $(71.4 \%)$ while the IFN-alpha2b alone sustained response had dropped to $10 \%(p=0.0003)$. These results suggest that the addition of Ta1 to IFN-alpha2b improves response rates and reduces relapses in difficult-to-treat precore mutant HBV infection. The results in patients who were previous interferon failures are particularly striking, in light of the fact that historical retreatment response rate with a second course of IFN-alpha would be expected to be no better than $10 \%$.

Several other studies also investigated the combination of Ta1 with IFN-alpha $[124,125]$ 
The combination of Ta1 with nucleoside analogs has also been tested in several clinical trials [126-128]. For example, a study was conducted in 11 immune-tolerant Chinese subjects with vertically transmitted CHB whose high HBV DNA and ALT levels made them highly unlikely to undergo spontaneous seroconversion to negative HBV DNA and HBeAg [129]. Treatment included Ta1, famiclovir, and lamivudine; the combination was well tolerated and $64 \%$ of subjects had a complete virological response. These data support the hypothesis that a combination of Tal and nucleoside analogues may be a safe and effective therapy for $\mathrm{CHB}$, especially in difficult-to-treat cases such as patients with vertically transmitted diseases and nonresponders to previous therapy.

\section{Chronic Hepatitis C (CHC)}

Hepatitis $\mathrm{C}$ is recognized as a global health problem, with an estimated worldwide prevalence of more than 185 million infected by the Hepatitis C Virus (HCV) and no available vaccine [130]. Although the hepatitis $\mathrm{B}$ and $\mathrm{C}$ viruses are not structurally related, they are similar in that they are both associated with a high incidence of liver disease, including cirrhosis and HCC. They both induce hepatocellular damage, whether through direct cytotoxicity or through induction of immune mechanisms that lead to hepatocellular necrosis. A covalent conjugate of recombinant IFN-alpha with a Polyethylene Glycol (PEG) moiety has been approved in combination with ribavirin and other direct-acting antiviral agents, for the treatment of $\mathrm{CHC}$.

Several studies investigated the therapeutic effect of Tal in combination with IFN-alpha for treatment of CHC. Three of these studies, two phase 2 studies in Italy $[131,132]$ and a phase 3 study in the United States [133] were analyzed independently using pooled and meta-analysis techniques. Results showed that Tal in combination with IFN-alpha was safe and significantly superior to IFN-alpha alone at the end of treatment $(p=0.01)$ [134].

Ta1 in combination with PEG-IFN-alpha has also been investigated in clinical trials. Two multicenter, double-blind, placebocontrolled phase 3 studies were conducted in the US, evaluating Ta1 in combination with PEG-IFN-alpha2a in 534 subjects with non-cirrhotic $\mathrm{CHC}$ and in 527 subjects with compensated cirrhosis, none of whom had responded to previous IFN-alpha or IFN-alpha plus ribavirin therapy. Ta1 was well tolerated overall, but the studies showed only a small effect on sustained viral responses in this subject population. Other studies have shown benefit from Tal when it was added to a combination of PEG-IFN-alpha and ribavirin treatment, however: a phase 2 trial in Mexico in $40 \mathrm{CHC}$ subjects who were non-responders to previous therapy with IFN-alpha plus ribavirin [135,136] had an end-of-treatment response rate of $53 \%$ and a sustained response rate of $21 \%$, an improvement over historical comparison studies.

A large European randomized, double-blind study with the same combination treatment of Ta1, PEG-IFN-alpha, and ribavirin was recently conducted in 553 subjects who had failed to respond to previous PEG-IFN-alpha/ribavirin treatment [137]. Results showed that $13 \%$ of Ta1-treated subjects achieved sustained responses at week 72 , versus $11 \%$ in the placebo group $(p=0.407)$. In the prospectively defined secondary population of subjects who completed the full course of 48 weeks of triple combination treatment, the primary endpoint achieved statistical significance for the difference in sustained viral response between the Ta1 treated group and the placebo group $(p=0.048)$.

\section{Human Immunodeficiency Virus (HIV)}

Acquired Immunodeficiency Syndrome (AIDS) is a disease of the human immune system caused by HIV infection. As the disease progresses, the immune system will slowly weaken, leading to a higher chance of infections that would not regularly occur in healthy patients. There is no cure or vaccine for HIV; however, antiretroviral treatments have shown to slow the course of the disease. Approximately 34 million people are living with HIV infection globally, while AIDS is considered a pandemic worldwide, having claimed more than 25 million lives (http://www.who.int/mediacentre/factsheets/fs360/en/index.html). Tal in combination with IFN-alpha and AZT was investigated for treatment of HIV in several studies [138,139] and several measures of response, including greater increases in CD4 cells, were seen in subjects given Ta1.

\section{Tal use in Treatment of Cancers}

The therapeutic usefulness of Tal has been examined in several types of cancers. Many cancer patients have depressed cellular immunity, and progression of some cancers appears to be related to impaired suppression of the tumors by the immune system. Immune modulation (e.g., with IL-2) has shown promising results for treatment of human cancers [140-142], and the results summarized below show that Ta1 also demonstrates usefulness in treating certain forms of cancer, although with none of the side effects of IL-2. Ta1 treatment has shown benefit to cancer patients in multiple different ways:

- Increase in effectiveness of chemotherapy, likely due to increases in tumor infiltrating lymphocytes, upregulation of antitumor $\mathrm{T}$ cells, and enhanced expression of cell-surface markers, as described above under Tal's mechanism of action

- Decrease in side effects of chemotherapy, possibly due to increases in regulatory $\mathrm{T}$ cells and subsequent decreases in proinflammatory cytokines

- Improvement in quality of life, as expected from responses to and decreases in side effects from chemotherapy

\section{Hepatocellular carcinoma (HCC)}

HCC is a primary malignancy of the liver responsible for over 600,000 deaths annually [143]. It is the third leading cause of cancer deaths worldwide, with the highest incidence in Asia and Africa due to the high prevalence of HBV and HCV. Symptoms include weight loss, signs of decompensated liver disease and right upper quadrant pain. Although surgical resection or liver transplant may benefit some patients, due to the advanced stage of cancer and liver disease at initial diagnosis, surgery may not be a viable option. Standard treatments for patients who cannot receive a liver transplant involve radiation and chemotherapies. Systemic chemotherapy results are at best dismal, although a number of reports have provided encouraging perspectives for regional chemotherapy. Transcatheter Arterial Chemoembolization (TACE) is a combination of regional chemotherapy and some form of hepatic artery occlusion. Consistently higher response rates have been reported for TACE when compared with systemic chemotherapy. For patients who have either failed TACE or who present with more advanced HCC, sorafenib (a multikinase inhibitor with activity against Raf-1, B-Raf, vascular endothelial growth factor receptor 2 , platelet-derived growth factor receptor, and c-Kit receptors, among other kinases) is now considered first-line treatment and has shown a clinically relevant improvement in time to progression and in survival.

Based on the immune-modulating mechanism of action of Tal, it is expected to be of benefit for use in combination with either sorafenib or TACE, with no addition of toxicity. A pilot study was conducted in Italy in 12 subjects with HCC to determine whether Ta1 could increase 
Citation: Tuthill CW, King RS (2013) Thymosin Apha 1 - A Peptide Immune Modulator with a Broad Range of Clinical Applications. Clin Exp Pharmacol 3: 133. doi:10.4172/2161-1459.1000133

Page 8 of 17

response to treatment with TACE in comparison to historical controls [144]. The addition of Tal to TACE led to a statistically significant increase in survival ( $82 \%$ versus $41 \%$; $p<0.05$ ), and significant increases in immune parameters (cytotoxic T cells and NK cells).

A Chinese study of 32 patients being treated with TACE for HCC also demonstrated that the addition of Ta1 improved response $[145,146]$, with a significant increase in survival compared to historical controls at 6,9 , and 12 months ( $p<0.05$; Figure 6). Ta1 treatment also significantly lowered alfa feto-protein levels and increased CD3 cells, CD4/CD8 ratio, and NK cells $(p<0.05)$.

Cheng et al. also evaluated the addition of Ta1 to TACE after tumor resection or partial hepatectomy, in a study in China of 57 subjects with HCC randomized to different treatment groups [147,148]. The addition of Ta1significantly improved survival (10 versus 7 months; $p=0.002)$ and delayed time to tumor recurrence $(p=0.039)$.

Cheng also evaluated the addition of Tal plus lamivudine combination therapy after tumor resection or partial hepatectomy in a study of 81 subjects with hepatitis B infection and HCC [149-151]. In this study, the addition of Ta1/lamivudine combination treatment resulted in a statistically significant increase in time to tumor recurrence ( 10.0 versus 6.5 months; $p=0.0032$ ), median survival time ( 12.5 versus 6.0 months; $p=0.0023$ ), and HBV-DNA clearance ( $100 \%$ versus $4 \%$; $p=0.0000)$ and seroconversion to $\mathrm{HBeAg}(73 \%$ versus $7.5 \%$; $p<0.05)$.

A further report by Cheng described the effect of Ta1 on subjects with HCC and portal vein tumor thrombus, being treated with surgery and TACE [152]. 84 subjects were randomized in various treatment groups, and it was seen that the addition of Tal improved median survival time (10 versus 7 months) and 1-year survival (44\% versus $15 \%)$, although the results were not significant.

In a study in the US, Gish also showed an improvement in response to TACE with the addition of Ta1 [153]; in 25 subjects randomized to TACE with or without Ta1, the addition of Ta1 led to improvements in response (57\% versus $46 \%$ ) and median overall survival (110 weeks versus 57 weeks).

\section{Non-small-cell lung cancer}

Lung cancer is estimated to be the most common form of cancer worldwide and to have the highest mortality rate (http://www. cancerresearchuk.org/cancer-info/cancerstats/world/lung-cancerworld/). Non-Small-Cell Lung Carcinoma (NSCLC) is any type of epithelial lung cancer excluding small cell lung carcinoma. NSCLC accounts for approximately $80 \%$ of all lung cancers with nearly $40 \%$ of the cases having already metastasized and at time of diagnosis (http:// lungcancer.about.com/od/typesoflungcancer/a/Where-Does-LungCancer-Spread.htm). NSCLS is typically treated by surgical resection due to the low efficacy of chemotherapy. Since NSCLC cannot be cured via current treatment modalities, palliative care is an important part of the standard treatment regimen.

Ta1 has been used to treat NSCLC in several different studies. The first randomized, double-blind trial with Ta1 was conducted in the US in 42 subjects with NSCLC being treated with radiation [154]. The addition of Tal after radiation therapy led to statistically significant improvement in relapse-free survival $(p=0.04)$, overall survival $(p=0.009)$, and immune cell function and numbers, which had been depleted by radiation treatment $(p=0.04)$.

Several studies in Italy reported that the addition of Tal to cisplatin/etoposide or ifosfamide chemotherapy in subjects with NSCLC led to an improvement in response and immune parameters compared (overall response rate of $44 \%$ and median survival of 12.6 months, Garaci 1995; time to progression of 18 weeks versus 9 weeks, $p=0.006$, Salvati 1996) $[155,156]$. The toxicity of the chemotherapy was decreased as well, as the percentage of subjects presenting with grade 3 or 4 myelosuppression was greatly decreased ( $0 \%$ versus $50 \%$ ).

Multiple clinical studies in China were also conducted; the first evaluated the addition of Ta1 to cisplatin/vinorelbine (NP) chemotherapy in NSCLC [157]. In a study of 69 subjects with stage III or IV cancer randomized to NP or NP with Ta1, after 4 monthly cycles of treatment the addition of Ta1 led to improvement in efficacy (from $21.2 \%$ to $38.9 \%$; $p<0.05$ ), median survival time (from 10.4 to 19.3 months), survival rates at $1,2,3$, and 4 years post-treatment $(p<0.05)$, and lymphocyte subsets $(p<0.05)$.

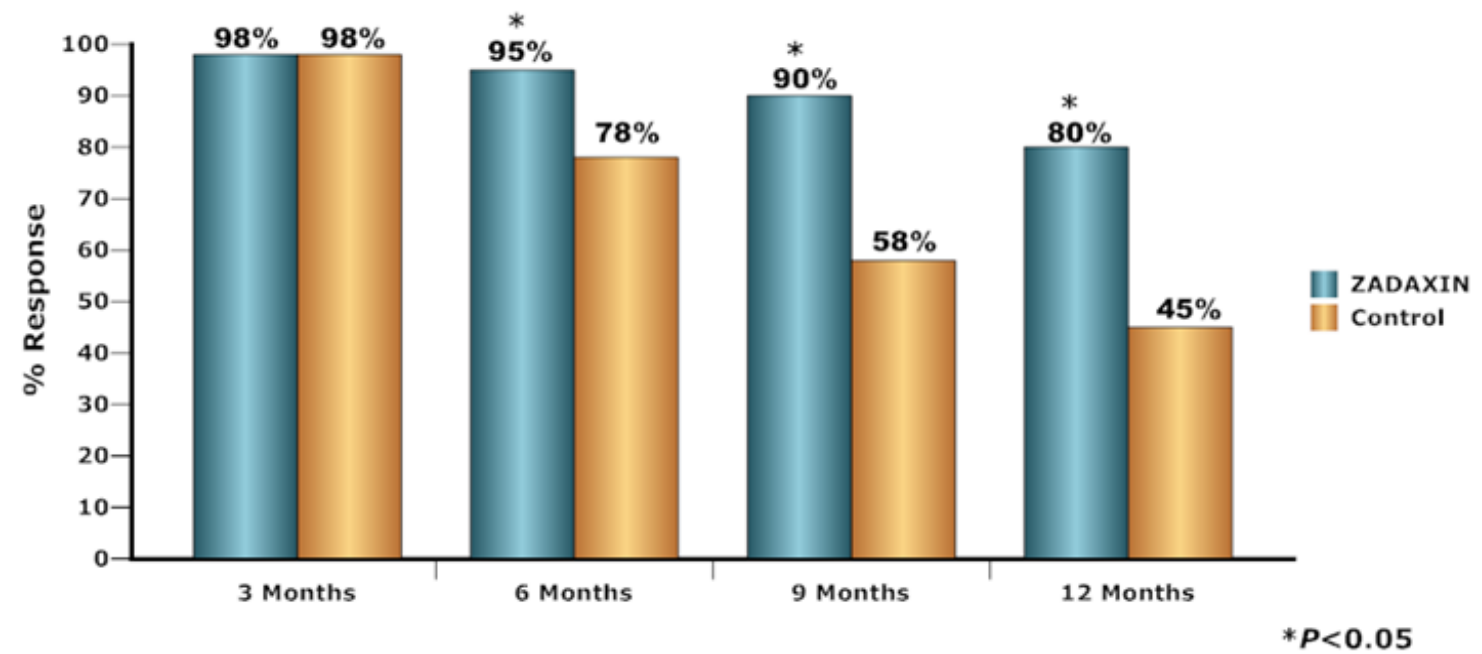

Abbreviations: $\mathrm{HCC}=$ hepatocellular carcinoma; TACE = transarterial chemoembolization; ZADAXIN = thymosin alpha 1

Figure 6: Ta1 improves survival in HCC treated with TACE. In a study with 32 Chinese patients being treated with TACE for HCC, the addition of Ta1 to the treatment (1.6 mg daily for 10 days) provided a significant increase in survival compared to historical controls at 6, 9, and 12 months after TACE [145, 146]. 
Hou reported a study with 68 subjects, also comparing NP alone with NP plus Ta1 [158]. The addition of Tal led to an improvement in clinical symptoms (from 47.1 to $73.5 \% ; p<0.05$ ), Quality Of Life (QOL) as determined by Karnovsky Performance Score (KPS; increased from 29.4 to $55.9 \% ; p<0.05$ ), and decreases in side effects from chemotherapy, as the percent of subjects suffering adverse effects (nausea and vomiting; depression in white blood cells and platelets) were decreased with Tal treatment $(p<0.05)$. The time to progression also increased from 5.8 to 7.1 months but this was not significant.

In another comparison study, 57 NSCLC subjects were given Ta1 in addition to cisplatin/navelbine chemotherapy [159]. The investigators reported improvements in immune parameters (increases in CD3 T cells, CD4 Th1 helper T cells, CD4/CD8 ratio, and NK cells; $p<0.05$ ) and an increase in efficacy along with no toxic side effects of treatment.

Sun also reported improvement in immune parameters in 68 subjects with NSCLC being treated with gemcitabine and cisplatin [160], and Liang saw significant improvements in QOL in a study with 58 elderly subjects comparing gemcitabine with gemcitabine plus Ta1 [161].

The 5 Chinese studies described above were recently included in a meta-analysis of randomized controlled trials in lung cancer using Cochrane criteria [162]. The meta-analysis concluded that the addition of Ta1 to cisplatin/vinorelbine led to an increase in overall tumor response rate (OR 1.86; 95\% CI 1.08-3.20), tumor control rate (OR 3.06; CI 1.36-6.88), 1-year survival rate (OR 3.05; CI 1.34-6.96), and QOL (OR 3.39; CI 1.54-7.47).

\section{Melanoma}

Melanoma is a cancer of the skin caused by a malignant tumor of melanocytes found predominantly in adults. Melanoma results in more than $75 \%$ of deaths caused by all skin cancers (http://www. cancer.org/cancer/cancercauses/sunandvexposure/skin-cancerfacts). If diagnosed early, patients with localized melanoma may be cured with surgery; however, there is no current cure for malignant melanoma after the cancer has metastasized. The average survival of patients with melanoma that has spread outside the local area is only about 8 months, with a 10 year survival rate of less than 10\% [163]. Early diagnosis of melanoma is essential for improving survivability. The World Health Organization has reported 48,000 deaths relating to melanoma worldwide [164].

Two small pilot studies showed beneficial effects compared to historical control when Tal treatment was added to Dacarbazine (DTIC) chemotherapy combined with IL-2 [165] or IFN-alpha [166].

These positive effects led to the conduct of a large, randomized study in Europe in 488 subjects with metastatic melanoma (Table 3 and Figure 7; Maio 2010) [167]. Addition of Ta1 to DTIC and IFN-alpha led to no further toxicity above the chemotherapy alone, but provided an increase in median Overall Survival (OS), Progression-Free Survival (PFS; significant for a dose of $3.2 \mathrm{mg}$ Tal plus DTIC compared to control, $p=0.04)$, tumor response $(p<0.05)$, and duration of response. Clinical benefit rates were significantly higher for subjects given $3.2 \mathrm{mg}$ Ta1 plus DTIC compared to control $(p=0.009)$.

\section{Other cancers}

Ta1 has been given to subjects with lung, gastric, or breast cancer in 2 separate studies in China. Tal was given to 60 subjects in each study during one of two cycles of chemotherapy and QOL was evaluated. Treatment with Ta1 provided a significant improvement in all measures of QOL (appetite, $p=0.0001$; sleep, $p=0.0002$; fatigue, $p=0.001$; daily activity, $p=0.0001$; overall feeling, $p=0.001$; depression, $p=0.003$ ) [168] as well as a lowered occurrence of infections during chemotherapy and increased immune parameters [169].

Ta1 was given to 26 subjects in China with pancreatic cancer [170] after intra-arterial chemotherapy with gemcitabine, 5-FU, mitomycin-c and octreotide. Subjects randomized to treatment with Ta1 had statistically significant increases in immune function (CD3, $\mathrm{CD} 4, \mathrm{CD} 4 / \mathrm{CD} 8$ ratio; $p<0.05)$ while control subjects had decreases in these parameters. Ten subjects from each group underwent subsequent surgery, and those treated with Ta1 had no severe postsurgical infections compared to 3 in the control group, a faster recovery time, and fewer side effects (neutropenia $8 \%$ versus $39 \%$; nausea and vomiting $31 \%$ vs $39 \%$; diarrhea $8 \%$ vs $23 \%$; fever $8 \%$ vs $23 \%$ ).

The effect of treatment with Ta1 was evaluated in 30 elderly subjects in China with advanced malignant cancer (lung, liver, stomach, colon, rectal; Yang 2003) [171], and showed a significant improvement in QOL (KPS) score $(p<0.01)$ and immune parameters $(p<0.05)$. Another study in a similar population of 60 subjects evaluated the addition of Tal to standard chemotherapy [172] and showed a significant increase in survival, from 6 to 24 months for $43 \%$ survival $(p<0.01)$, a significant increase in QOL (KPS) score $(p<0.01)$, and improvements in immune function $(\mathrm{CD} 4 / \mathrm{CD} 8$ ratio and NK cells; $p<0.05)$. The effect of Ta1 addition was so strong that at 24 months, when $43 \%$ survival was seen in the Ta1-treated group, the control group of subjects in the study had no survivors at all.

Twenty-two subjects in China with lung or breast cancer who had neurotoxicity after treatment with chemotherapy (grades 2-4) were treated with Ta1 during one of their chemotherapy cycles [173,174]. After this combination treatment 10 of the subjects (45.4\%) had a decrease in neurotoxicity scores (from 2 and 3 down to 0 and 1).

A pilot Chinese study evaluated the effect of Tal on QOL in 16 post-menopausal women undergoing treatment for breast cancer with aromatase inhibitors who had joint symptoms and pain related to the treatment [175]. After treatment with Ta1, all subjects reported statistically significant improvement in worst pain scores (decreasing from a score of 5.7 to $3.4 ; p<0.001$ ), pain severity (from 3.9 to 2.9 ; $p<0.01$ ), and pain-related functional interference (4.2 to $1.8 ; p<0.001)$ using the Brief Pain Inventory (BPI) scale. Significant improvement was also seen in the Western Ontario and McMaster Universities

\begin{tabular}{|c|c|c|c|c|c|c|}
\hline & $\begin{array}{c}\text { DTIC IFN } \\
1.6 \mathrm{mg} \mathrm{Ta} 1(\mathrm{~N}=97)\end{array}$ & $\begin{array}{c}\text { DTIC IFN } \\
3.2 \mathrm{mg} \mathrm{Ta} 1(\mathrm{~N}=97)\end{array}$ & $\begin{array}{c}\text { DTIC IFN } \\
6.4 \mathrm{mg} \mathrm{Ta} 1 \quad(\mathrm{~N}=98)\end{array}$ & $\begin{array}{c}\text { DTIC Ta1 } \\
(3.2 \mathrm{mg})(\mathrm{N}=99)\end{array}$ & $\begin{array}{l}\text { Combined Total } \\
\text { Ta1 }(\mathrm{N}=391)\end{array}$ & $\begin{array}{c}\text { DTIC IFN } \\
\text { (Control) }(\mathrm{N}=95)\end{array}$ \\
\hline Median overall survival (months) & 9.3 & 8.6 & 10.3 & 9.3 & 9.4 & 6.6 \\
\hline Progression-free survival 6 months (\%) & 12 & 21 & 13 & 16 & 16 & 9 \\
\hline Overall tumor response number (\%) & $7(7.2 \%)$ & $10(10.3 \%)$ & $6(6.1 \%)$ & $12(12.1 \%)$ & $35(9.0 \%)$ & $4(4.1 \%)$ \\
\hline
\end{tabular}

Abbreviations: DTIC = dacarbazine; IFN = interferon; $\mathrm{N}=$ number; Ta1 = thymosin alpha 1

Table 3: Ta1 improves OS, PFS, and tumor response in stage IV melanoma. 


\section{1-Year Overall Survival}

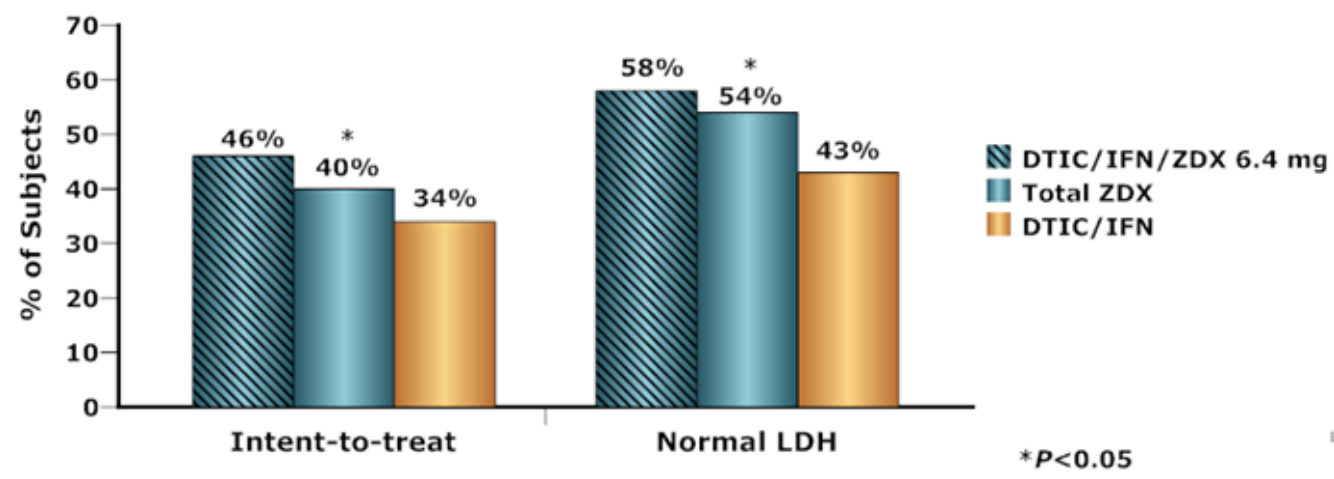

\section{2-Year Overall Survival}

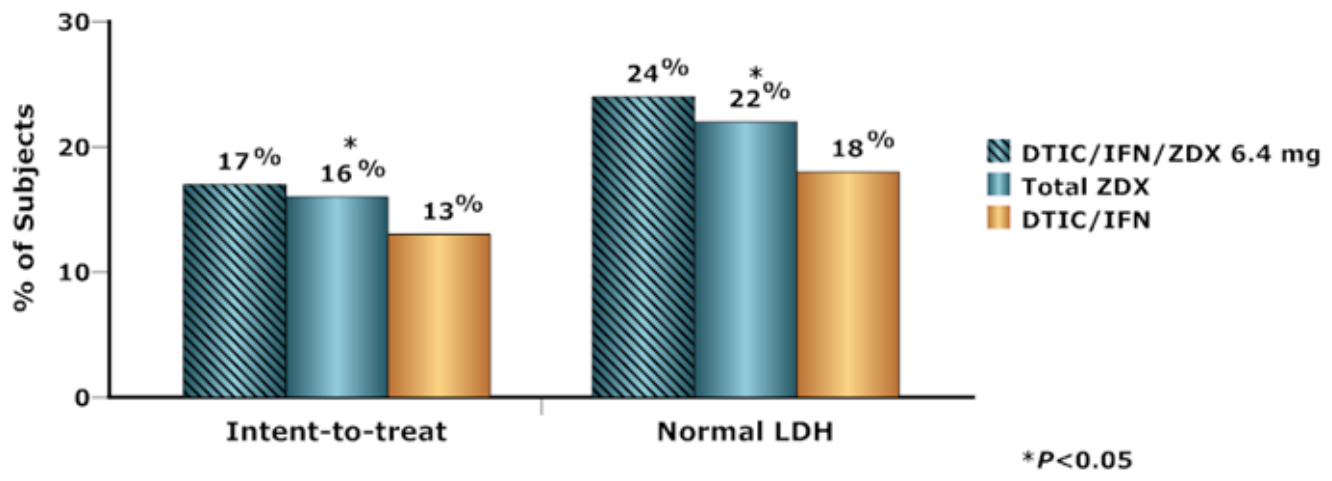

Abbreviations: DTIC = dacarbazine; IFN = interferon; $L D H=$ lactate dehydrogenase; ZDX = thymosin alpha 1

Figure 7: Ta1 prolongs survival in stage IV melanoma. In a European study with 488 subjects, addition of Ta1 to DTIC chemotherapy led to a statistically significant improvement in overall survival, especially in patients with normal lactate dehydrogenase (LDH) levels [167].

Osteoarthritis Index (WOMAC; $p<0.001$ ) and Functional Assessment of Cancer Therapy-General physical well-being (FACT-G; $p<0.001$ ).

\section{Tal use in Vaccine Enhancement}

Decreased antibody response to T-cell dependent antigens, particularly in the elderly, may be one factor that accounts for insufficient efficacy of certain vaccination programs (e.g., influenza). Immune senescence, a normal aging process, has been related to a gradual decline in thymus function and thymic hormone production. The lack of thymic hormones may contribute to the decline in immune function, particularly the T-cell component $[176,177]$. In the elderly, for example, analysis of a specific antibody response after vaccination has been shown to be impaired when compared with response in young subjects $[52,178,179]$. Diminished antibody responses have also been reported in patients with end-stage renal disease. The evidence for impairment of cell mediated immunity in hemodialysis patients has been attributed to incompetence in T-cell-mediated immune responses [179-183]. Several studies have reported poor antibody response after hepatitis B vaccination in hemodialysis patients [184-186].

Since Tal can enhance T-cell-dependent specific antibody production, the addition of Tal to vaccination protocols for immunocompromised individuals should be effective. In vaccinated elderly individuals, in vitro influenza antibody synthesis was augmented with the addition of Ta1 [52]. Enhancement of specific antibody responses to tetanus toxoid and sheep red blood cells also was observed by the in vivo administration of Tal to older mice or mice immunosuppressed with cocaine [51,53]. These experimental data support that Ta1, when appropriately administered with a vaccine, could enhance immune function and antibody response in individuals with a compromised immune system.

Six clinical studies have been completed that evaluated the efficacy of Tal as an adjuvant for influenza or hepatitis $\mathrm{B}$ vaccines in subjects immunocompromised due to age or hemodialysis. When compared with vaccine plus placebo, administration of Ta1 in conjunction with vaccine increased and sustained the specific antibody response, increased protection against illness, and overcame previous lack of specific antibody response and age-associated decline in specific antibody response. The studies also show that $\mathrm{Tal}$ is safe for administration to immunocompromised subjects, including the elderly, and no serious adverse effects were observed in any of the studies.

\section{Elderly subjects}

The immune enhancing effect of Ta1 for influenza vaccination was first examined in a pilot study with 9 elderly subjects (ages 65-99 years) at the University of Wisconsin and Cornell Medical Center [187]. In this study, 67\% (6/9) of Tal subjects responded with high levels of antiinfluenza antibodies, compared to a historical typical revaccination response rate of only $10 \%$. 
Citation: Tuthill CW, King RS (2013) Thymosin Apha 1 - A Peptide Immune Modulator with a Broad Range of Clinical Applications. Clin Exp Pharmacol 3: 133. doi:10.4172/2161-1459.1000133

Page 11 of 17

This study was followed by a double-blind, randomized, placebocontrolled study in 90 male veterans $>64$ years of age (mean age 77.3 years; age range 65 to 99 years) at the Wisconsin Veterans' Administration Medical Center [188]. The study showed that $69 \%$ of Ta1 subjects were effectively immunized to the trivalent influenza vaccine versus $52 \%$ of placebo subjects $(p=0.023)$. The difference between treatment groups was greater in subjects older than 77 years. There was, as expected, a relationship between antibody levels and age $(p<0.039)$; antibody levels declined with age in placebo subjects but remained stable with age in Tal-treated subjects, and in fact antibody levels in Ta1-treated older subjects were increased to levels seen in younger subjects.

Based on these encouraging results, a larger study was conducted at George Washington University with 330 subjects vaccinated with the trivalent influenza vaccine (B/Ann Arbor, A/H3N2 Leningrad and A/ H1N1 Taiwan). As reported [189], there were greater A/H1N1 Taiwan antibody levels in subjects receiving 8 doses of Tal than subjects receiving only 4 injections or none $(p=0.015)$. Importantly, there was a lower incidence of influenza disease in subjects receiving the 8 doses of Tal compared to those who did not receive Ta1 ( $p=0.002$; Figure 8 ). The greatest effect was observed in subjects 80 years or older.

\section{Hemodialysis subjects}

Three separate randomized, double-blinded, placebo controlled studies evaluated the adjuvant effect of Tal on vaccines in subjects immunocompromised by chronic renal failure and undergoing hemodialysis.

A study in the US was conducted in 23 subjects on hemodialysis who were nonresponders to a course of Heptavax ${ }^{\mathrm{m}}$ hepatitis $\mathrm{B}$ vaccination. The subjects were revaccinated with the three-course vaccine, and half the subjects were given Tal after each vaccine [190,191]. After 3 months, there was a significant difference in the number of patients producing clinically significant antibody titers between the Ta1-treated and placebo subjects (64\% versus $17 \% ; p<0.002$ ). After 12 months, $45 \%$ of Ta1-treated subjects had retained sustained, clinically significant antibody titers, while $0 \%$ of placebo-treated subjects $\operatorname{did}(p<0.002)$.

Another US study with 97 hemodialysis subjects was conducted with monovalent $\mathrm{A} /$ Taiwan/1/86 (H1N1) influenza vaccine [192]. At 4 weeks post vaccination, $71 \%$ of Tal-treated subjects had responded compared to only $43 \%$ of placebo-treated subjects $(p<0.002)$. At 8 weeks post vaccination, $65 \%$ of Ta1-treated subjects were still protected with circulating levels of antibody; however the placebo response had decreased to only $24 \%(p<0.001)$.

In a recent study conducted in Italy, the effect of Tal on vaccination response to $2009 \mathrm{H} 1 \mathrm{~N} 1$ monovalent, adjuvant influenza vaccine (Focetria ${ }^{\oplus}$, Novartis) in 82 subjects with end-stage renal disease on chronic hemodialysis was evaluated [193]. The Tal treatment regiment was simplified compared to the previous studies, however, as there were only 2 injections of Ta1, given 7 days prior to vaccination and on the day of vaccination (rather than the previous 4 or 8 injections). The dose was higher ( 3.2 or $6.4 \mathrm{mg}$, compared to the previous $1.6 \mathrm{mg}$ ) in hope that that the fewer injections could still provide benefit. The study showed that response to vaccination was significantly increased in both Ta1-treated groups compared to placebo (Figure 9). These results are particularly striking in light of the fact that Ta1 provided a strong benefit in combination with a vaccine that already contained an adjuvant.

\section{Conclusions}

Since its discovery in $1979, \mathrm{Ta} 1$ has been evaluated in over 80 clinical studies and administered to more than 230,000 patients in postmarketing experience. Administration has been in daily doses ranging from 0.6 to $9.6 \mathrm{mg} / \mathrm{m}^{2}$ and $1 \mathrm{mg}$ to $16 \mathrm{mg}$, primarily administered subcutaneously on a biweekly schedule, for treatment periods ranging from 1 day to 18 months. Tal has been well tolerated and has not been associated with any significant side effects. Tal has been administered without adverse incidents to elderly subjects (up to 101 years old), children (as young as 13 months), and immunocompromised patients. Tal has been shown to be well tolerated even in patients with poor performance status, including those with liver disease, renal disease requiring hemodialysis, and primary immunodeficient individuals. The lack of significant side effects with Ta1 is in sharp contrast to other major immune response modulators such as IFN-alpha and IL-2. The side effects and toxicities of the latter drugs make them difficult

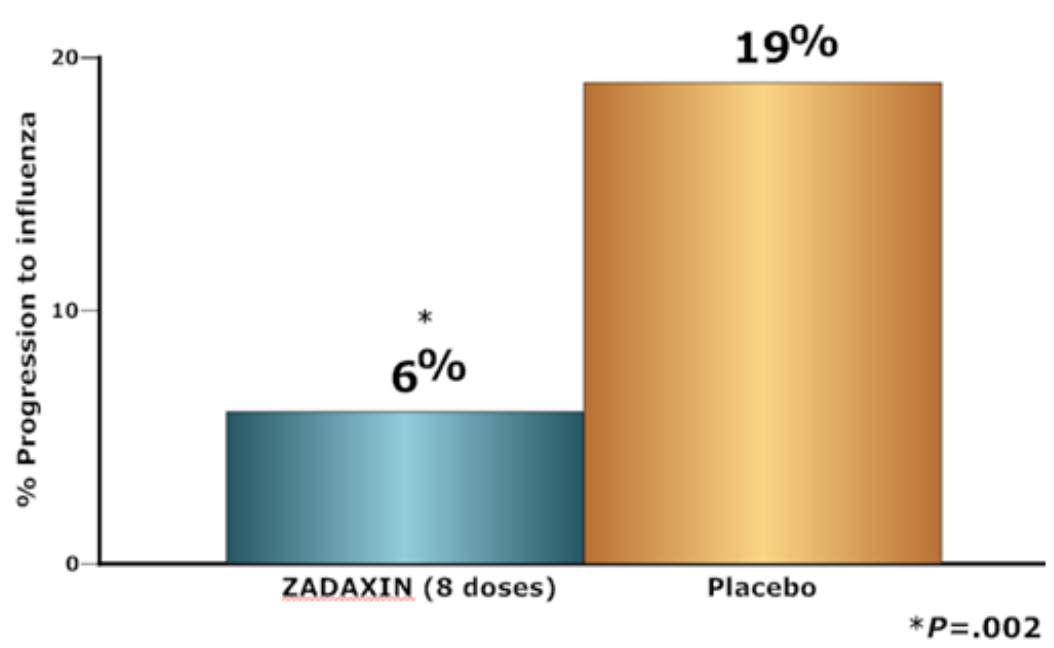

Abbreviations: ZADAXIN = thymosin alpha 1

Figure 8: Lower incidence of influenza in subjects who received Ta1 after influenza vaccine. In a study with 330 subjects vaccinated with the trivalent influenza vaccine (B/Ann Arbor, A/H3N2 Leningrad, A/H1N1 Taiwan), there was a lower incidence of subsequent influenza disease in subjects receiving 8 doses of Ta1 compared to those who did not receive Ta1 [189]. 
Citation: Tuthill CW, King RS (2013) Thymosin Apha 1 - A Peptide Immune Modulator with a Broad Range of Clinical Applications. Clin Exp Pharmacol 3: 133. doi:10.4172/2161-1459.1000133

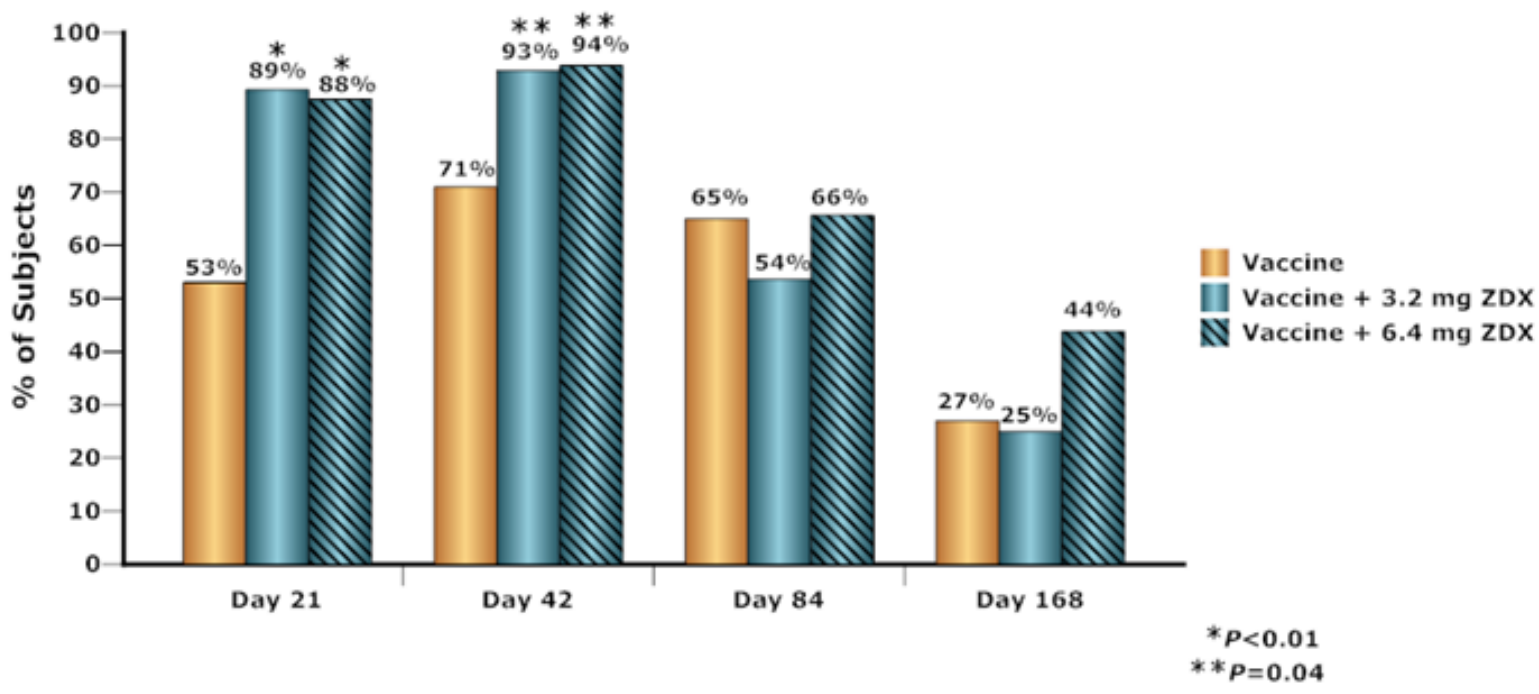

Abbreviations: ESRD = end-stage renal dialysis; ZDX = thymosin alpha 1

Figure 9: Ta1 improves response to H1N1 2009 influenza vaccine. A study with 120 adults with end-stage renal disease (ESRD) on chronic dialysis were given the egg-derived $2009 \mathrm{H} 1 \mathrm{~N} 1$ monovalent vaccine (Focetria ${ }^{\circledR}$, Novartis) with or without Ta1 (7 days prior to vaccination as well as on the day of vaccination) [193]. Those treated with Ta1 achieved a marked increase in seroconversion which lasted up to 42 days after vaccination.

for most patients to tolerate. For example, IFN-alpha results in flulike side effects (fever, chills, malaise, and headaches), neutropenia, thrombocytopenia and depression. IL-2 causes significant edema (capillary-leak syndrome) in the lungs and elsewhere. Thus, while Ta1 is one of only a few immunomodulators that have been approved for human use, it does not appear to induce any of the side effects and toxicities commonly associated with agents in this class, resulting from the interesting TLR9-based mechanism of action as described above. Taken together, the clinical data reviewed here show that Ta1 has great promise as an immune modulator for benefit of a wide array of clinical indications.

Conflicts of interest: Both Cynthia Tuthill and Robert King work at SciClone Pharmaceuticals, Inc., the company that holds commercial rights for ZADAXIN thymosin alpha 1.

\section{References}

1. Low TL, Goldstein AL (1979) The chemistry and biology of thymosin. II. Amino acid sequence analysis of thymosin alpha1 and polypeptide beta1. J Biol Chem 254: 987-995.

2. Low TL, Thurman GB, McAdoo M, McClure J, Rossio JL, et al. (1979) The chemistry and biology of thymosin. I. Isolation, characterization, and biological activities of thymosin alpha1 and polypeptide beta1 from calf thymus. J Biol Chem 254: 981-986.

3. Oates KK, Erdos M (1989) Biochemical identification of thymosin alpha-1: its phylogenetic distribution and evolutionary implications. Comp Biochem Physio B 94: 759-763.

4. Weller FE, Shah U, Cummings GD, Chretien PB, Mutchnick MG (1992) Serum levels of immunoreactive thymosin alpha 1 and thymosin beta 4 in large cohorts of healthy adults. Thymus 19: 45-52.

5. Jevremovic M, Kartaljevic G, Jelusic V, Vodnik T, Pesic M, et al. (1997) Determination of thymosin alpha 1 with enzyme-immunoassay in colorectal cancer patients. Arch Oncol 5: 193-194.

6. Sherman KE, Jones CC, Goldstein AL, Naylor PH (1991) Low thymosin alpha-1 concentrations in patients chronically infected with the hepatitis $B$ virus. Viral Immunol 4: 195-199.

7. Welch RA, Mutchnick MG, Weller FE, Sokol RJ (1987) Maternal and fetal circulating levels of thymosin alpha 1 during parturition. Am J Reprod Immuno Microbiol 13: 125-127.

8. Welch RA, Lee HH, Sokol RJ, Mutchnick MG (1988) Amniotic fluid thymosin alpha 1 levels increase during gestation. Am J Reprod Immunol Microbiol 17 96-97.

9. Grottesi A, Sette M, Palamara T, Rotilio G, Garaci E, et al. (1998) The conformation of peptide thymosin alpha 1 in solution and in a membrane-like environment by circular dichroism and NMR spectroscopy. A possible model for its interaction with the lymphocyte membrane. Peptides 19: 1731-1738.

10. Elizondo-Riojas MA, Chamow SM, Tuthill CW, Gorenstein DG, Volk DE (2011) NMR structure of human thymosin alpha-1. Biochem Biophys Res Commun 416: 356-361.

11. Yao Q, Doan LX, Zhang R, Bharadwaj U, Li M, et al. (2007) Thymosin-alpha1 modulates dendritic cell differentiation and functional maturation from human peripheral blood CD14+ monocytes. Immunol Lett 110: 110-120.

12. Zhang P, Chan J, Dragoi AM, Gong X, Ivanov S, et al. (2005) Activation of IKK by thymosin alpha1 requires the TRAF6 signalling pathway. EMBO Rep 6: $531-537$.

13. Shiau AL, Wu CL, Huang KY (1988) The effect of thymosin on experimental herpes simplex virus infections. Taiwan Yi Xue Hui Za Zhi 87: 34-42.

14. Favalli C, Mastino A, Jezzi T, Grelli S, Goldstein AL, et al. (1989) Synergistic effect of thymosin alpha 1 and alpha beta-interferon on NK activity in tumorbearing mice. Int J Immunopharmacol 11: 443-450.

15. Mastino A, Favalli C, Grelli S, Rasi G, Pica F, et al. (1992) Combination therapy with thymosin alpha 1 potentiates the anti-tumor activity of interleukin-2 with cyclophosphamide in the treatment of the Lewis lung carcinoma in mice. Int $\mathrm{J}$ Cancer 50: 493-499.

16. Garaci E, Mastino A, Pica F, Favalli C (1990) Combination treatment using thymosin alpha 1 and interferon after cyclophosphamide is able to cure Lewis lung carcinoma in mice. Cancer Immunol Immunother 32: 154-160.

17. Garaci E, Mastino A, Favalli C (1989) Enhanced immune response and antitumor immunity with combinations of biological response modifiers. Bull $N$ Y Acad Med 65: 111-119.

18. Umeda Y, Sakamoto A, Nakamura J, Ishitsuka H, Yagi Y (1983) Thymosin alpha 1 restores NK-cell activity and prevents tumor progression in mice immunosuppressed by cytostatics or X-rays. Cancer Immunol Immunother 15: 78-83.

19. Garaci E, Pica F, Mastino A, Palamara AT, Belardelli F, et al. (1993) Antitumor 
Citation: Tuthill CW, King RS (2013) Thymosin Apha 1 - A Peptide Immune Modulator with a Broad Range of Clinical Applications. Clin Exp Pharmacol 3: 133. doi:10.4172/2161-1459.1000133

Page 13 of 17

effect of thymosin alpha $1 /$ interleukin-2 or thymosin alpha 1 /interferon alpha,beta following cyclophosphamide in mice injected with highly metastatic Friend erythroleukemia cells. J Immunother Emphasis Tumor Immunol 13: 7-17.

20. Di Francesco P, Pica F, Gaziano R, Favalli C, Garaci E (1994) In vivo recovery of natural killer cell activity by the association of thymosin alpha 1 and cytokines during cocaine administration. Medical Science Research 22: 41-42.

21. Favalli C, Jezzi T, Mastino A, Rinaldi-Garaci C, Riccardi C, et al. (1985) Modulation of natural killer activity by thymosin alpha 1 and interferon. Cancer Immunol Immunother 20: 189-192.

22. Rasi G, Silecchia G, Sinibaldi-Vallebona P, Spaziani E, Pierimarchi $P$, et al (1994) Anti-tumor effect of combined treatment with thymosin alpha 1 and interleukin-2 after 5-fluorouracil in liver metastases from colorectal cancer in rats. Int J Cancer 57: 701-705.

23. Silecchia G, Guarino E, Sinibaldi-Vallebona P, Pierimarchi P, Restuccia A, et al. (1999) Efficacy of repeated cycles of chemo-immunotherapy with thymosin alpha1 and interleukin-2 after intraperitoneal 5-fluorouracil delivery. Cancer Immunol Immunother 48: 172-178.

24. Serrate SA, Schulof RS, Leondaridis L, Goldstein AL, Sztein MB (1987) Modulation of human natural killer cell cytotoxic activity, lymphokine production, and interleukin 2 receptor expression by thymic hormones. J Immunol 139 : 2338-2343.

25. Garaci E, Rocchi G, Perroni L, D’Agostini C, Soscia F, et al. (1994) Combination treatment with zidovudine, thymosin alpha 1 and interferon-alpha in human immunodeficiency virus infection. Int J Clin Lab Res 24: 23-28.

26. Peng Y, Chen Z, Yu W, Zhou Q, Xu L, et al. (2008) Effects of thymic polypeptides on the thymopoiesis of mouse embryonic stem cells. Cell Biol Int 32: $1265-1271$

27. Loggi E, Gramenzi A, Margotti M, Cursaro C, Galli S, et al. (2008) In vitro effect of thymosin-alpha1 and interferon-alpha on Th1 and Th2 cytokine synthesis in patients with eAg-negative chronic hepatitis B. J Viral Hepat 15: 442-448.

28. Cursaro C, Margotti M, Favarelli L, et al. (1998) Thymosina1 (Ta1) plus interferona (IFNa) enhance the immune and antiviral response of patients with hepatitis $\mathrm{C}$ virus infection. Hepatology 28: $361 \mathrm{~A}$

29. Sztein MB, Serrate SA, Goldstein AL (1986) Modulation of interleukin 2 receptor expression on normal human lymphocytes by thymic hormones. Proc Natl Acad Sci U S A 83: 6107-6111.

30. Sztein MB, Serrate SA (1989) Characterization of the immunoregulatory properties of thymosin alpha 1 on interleukin-2 production and interleukin-2 receptor expression in normal human lymphocytes. Int $\mathrm{J}$ Immunopharmacol 11: $789-800$

31. Leichtling KD, Serrate SA, Sztein MB (1990) Thymosin alpha 1 modulates the expression of high affinity interleukin-2 receptors on normal human lymphocytes. Int J Immunopharmacol 12: 19-29.

32. Svedersky LP, Hui A, May L, McKay P, Stebbing N (1982) Induction and augmentation of mitogen-induced immune interferon production in human peripheral blood lymphocytes by $\mathrm{N}$ alpha-desacetylthymosin alpha 1 . Eur $\mathrm{J}$ Immunol 12: 244-247.

33. Hsia J, Sarin N, Oliver JH, Goldstein AL (1989) Aspirin and thymosin increase interleukin-2 and interferon-gamma production by human peripheral blood lymphocytes. Immunopharmacology 17: 167-173.

34. Mutchnick MG, Appelman HD, Chung HT, Aragona E, Gupta TP, et al. (1991) Thymosin treatment of chronic hepatitis B: a placebo-controlled pilot trial. Hepatology 14: 409-415.

35. Pica F, Fraschetti M, Matteucci C, Tuthill C, Rasi G (1998) High doses of thymosin alpha 1 enhance the anti-tumor efficacy of combination chemoimmunotherapy for murine B16 melanoma. Anticancer Res 18: 3571-3578.

36. Romani L, Bistoni F, Gaziano R, Bozza S, Montagnoli C, et al. (2004) Thymosin alpha 1 activates dendritic cells for antifungal Th1 resistance through toll-like receptor signaling. Blood 103: 4232-4239.

37. Romani L, Bistoni F, Perruccio K, Montagnoli C, Gaziano R, et al. (2006) Thymosin alpha1 activates dendritic cell tryptophan catabolism and establishes a regulatory environment for balance of inflammation and tolerance. Blood 108: 2265-2274.

38. Romani L, Bistoni F, Montagnoli C, Gaziano R, Bozza S, et al. (2007) Thymosin alpha1: an endogenous regulator of inflammation, immunity, and tolerance. Ann N Y Acad Sci 1112: 326-338.

39. Romani L, Moretti S, Fallarino F, Bozza S, Ruggeri L, et al. (2012) Jack of al trades: thymosin $\hat{I} \pm 1$ and its pleiotropy. Ann N Y Acad Sci 1269: 1-6.

40. Shrivastava P, Singh SM, Singh N (2004) Effect of thymosin alpha 1 on the antitumor activity of tumor-associated macrophage-derived dendritic cells. J Biomed Sci 11: 623-630.

41. Minkis K, Kavanagh DG, Alter G, Bogunovic D, O'Neill D, et al. (2008) Type 2 Bias of $T$ cells expanded from the blood of melanoma patients switched to type 1 by IL-12p70 mRNA-transfected dendritic cells. Cancer Res 68: 9441-9450.

42. Colombo MP, Trinchieri G (2002) Interleukin-12 in anti-tumor immunity and immunotherapy. Cytokine Growth Factor Rev 13: 155-168.

43. Haanen JB, Baars A, Gomez R, et al. (2006) Melanoma-specific tumorinfiltrating lymphocytes but not circulating melanoma-specific $T$ cells may predict survival in resected advanced-stage melanoma patients. Cancer Immunol Immunother 55: 451-458.

44. Wang RF, Miyahara Y, Wang HY (2008) Toll-like receptors and immune regulation: implications for cancer therapy. Oncogene 27: 181-189.

45. Kim HA, Ko HM, Ju HW, Kim KJ, Roh SG, et al. (2009) CpG-ODN-based immunotherapy is effective in controlling the growth of metastasized tumor cells. Cancer Lett 274: 160-164.

46. Kirkwood JM, Tarhini AA, Panelli MC, Moschos SJ, Zarour HM, et al. (2008) Next generation of immunotherapy for melanoma. J Clin Oncol 26: 3445-3455.

47. lijima N, Yanagawa Y, Onoé K (2003) Role of early- or late-phase activation of p38 mitogen-activated protein kinase induced by tumour necrosis factoralpha or 2,4-dinitrochlorobenzene during maturation of murine dendritic cells. Immunology 110: 322-328.

48. Arrighi JF, Rebsamen M, Rousset F, Kindler V, Hauser C (2001) A critical role for p38 mitogen-activated protein kinase in the maturation of human bloodderived dendritic cells induced by lipopolysaccharide, TNF-alpha, and contact sensitizers. J Immunol 166: 3837-3845.

49. Nefedova Y, Huang M, Kusmartsev S, Bhattacharya R, Cheng P, et al. (2004) Hyperactivation of STAT3 is involved in abnormal differentiation of dendritic cells in cancer. J Immunol 172: 464-474.

50. Yoshimura S, Bondeson J, Brennan FM, Foxwell BM, Feldmann M (2001) Role of NFkappaB in antigen presentation and development of regulatory $\mathrm{T}$ cells elucidated by treatment of dendritic cells with the proteasome inhibitor PSI. Eu J Immunol 31: 1883-1893.

51. Ershler WB, Hebert JC, Blow AJ, Granter SR, Lynch J (1985) Effect of thymosin alpha one on specific antibody response and susceptibility to infection in young and aged mice. Int J Immunopharmacol 7: 465-471.

52. Ershler WB, Moore AL, Socinski MA (1984) Influenza and aging: age-related changes and the effects of thymosin on the antibody response to influenza vaccine. J Clin Immunol 4: 445-454.

53. Effros RB, Casillas A, Walford RL (1988) The effect of thymosin alpha 1 on immunity to influenza in aged mice. Aging: Immunology and Infectious Disease Vol 1, New York, NY: Mary Ann Liebert, Inc., 31-40.

54. Clemente CG, Mihm MC Jr, Bufalino R, Zurrida S, Collini P, et al. (1996) Prognostic value of tumor infiltrating lymphocytes in the vertical growth phase of primary cutaneous melanoma. Cancer 77: 1303-1310.

55. Osheroff PL (1981) The effect of thymosin on glucocorticoid receptors in Iymphoid cells. Cell Immunol 60: 376-385.

56. Baumann CA, Badamchian M, Goldstein AL (1997) Thymosin alpha 1 antagonizes dexamethasone and CD3-induced apoptosis of CD4+ CD8+ thymocytes through the activation of CAMP and protein kinase $C$ dependent second messenger pathways. Mech Ageing Dev 94: 85-101.

57. Knutsen AP, Freeman JJ, Mueller KR, Roodman ST, Bouhasin JD (1999) Thymosin-alpha1 stimulates maturation of CD34+ stem cells into CD3+4+ cells in an in vitro thymic epithelia organ coculture model. Int $\mathrm{J}$ Immunopharmaco 21: $15-26$

58. Ho AD, Stehle B, Dietz G, Hunstein W, Hoffbrand AV (1985) Termina differentiation of cord blood lymphocytes induced by thymosin fraction 5 and thymosin alpha 1. Scand J Immunol 21: 221-225.

59. Ohta Y, Sueki K, Yoneyama Y, Tezuka E, Yagi Y (1983) Immunomodulating 
Citation: Tuthill CW, King RS (2013) Thymosin Apha 1 - A Peptide Immune Modulator with a Broad Range of Clinical Applications. Clin Exp Pharmacol 3: 133. doi:10.4172/2161-1459.1000133

activity of thymosin fraction 5 and thymosin alpha 1 in immunosuppressed mice. Cancer Immunol Immunother 15: 108-113.

60. Ohta Y, Tezuka E, Tamura S, Yagi Y (1985) Thymosin alpha 1 exerts protective effect against the 5-FU induced bone marrow toxicity. Int J Immunopharmacol 7: 761-768.

61. Hu SK, Low TL, Goldstein AL (1981) Modulation of terminal deoxynucleotidy transferase activity by thymosin. Mol Cell Biochem 41: 49-58.

62. Pierluigi B, D'Angelo C, Fallarino F, Moretti S, Zelante T, et al. (2010) Thymosin alpha1: the regulator of regulators? Ann N Y Acad Sci 1194: 1-5.

63. Giuliani C, Napolitano G, Mastino A, Di Vincenzo S, D'Agostini C, et al (2000) Thymosin-alpha1 regulates MHC class I expression in FRTL-5 cells at transcriptional level. Eur J Immunol 30: 778-786

64. Sinibaldi Vallebona P, Pierimarchi P, Moroni G, et al. (2002) Thymalfasin upregulates tumor antigen expression in colorectal cancer cells. XXXth Meeting of the International Society for Oncodevelopmental Biology and Medicine.

65. Garaci E, Pica F, Serafino A, Balestrieri E, Matteucci C, et al. (2012) Thymosin Ît1 and cancer: action on immune effector and tumor target cells. Ann N Y Acad Sci 1269: 26-33.

66. Kageshita T, Hirai S, Ono T, Hicklin DJ, Ferrone S (1999) Down-regulation of HLA class I antigen-processing molecules in malignant melanoma: association with disease progression. Am J Pathol 154: 745-754.

67. Chang CC, Ogino T, Mullins DW, Oliver JL, Yamshchikov GV, et al. (2006) Defective human leukocyte antigen class l-associated antigen presentation caused by a novel beta2-microglobulin loss-of-function in melanoma cells. J Biol Chem 281: 18763-18773.

68. Palamara A, Bue M, Savini P, et al. (1998) Thymosin alpha 1 inhibits Sendai virus replication: involvement of intracellular redox state. 6th International Expert Forum of Immunotherapy and Gene Therapy.

69. Moody TW, Fagarasan M, Zia F, Cesnjaj M, Goldstein AL (1993) Thymosin alpha 1 down-regulates the growth of human non-small cell lung cancer cells in vitro and in vivo. Cancer Res 53: 5214-5218.

70. Moody T, Badamchian M, Goldstein A (1998) Thymosin alpha 1 prevents lung carcinogenesis. FASEB Journal 12: A1457.

71. Bepler G (1994) Thymosin alpha-1 as adjunct for conventional therapy of malignant tumors: a review. Cancer Invest 12: 491-496.

72. Oates KK, Goldstein AL (1995) Thymosin. In: DeVita VT, Hellman S, Rosenberg SA, eds. Biological Therapy of Cancer. 2nd ed. Philadelphia: Lippincott, J B, 841-852.

73. Garaci E, Pica F, Rasi G, Favalli C (2000) Thymosin alpha 1 in the treatment of cancer: from basic research to clinical application. Int $\mathrm{J}$ Immunopharmacol 22: $1067-1076$

74. Rasi G, Pierimarchi P, Sinibaldi Vallebona P, Colella F, Garaci E (2003) Combination therapy in the treatment of chronic viral hepatitis and prevention of hepatocellular carcinoma. Int Immunopharmacol 3: 1169-1176.

75. Goldstein AL, Badamchian M (2004) Thymosins: chemistry and biological properties in health and disease. Expert Opin Biol Ther 4: 559-573.

76. Garaci E, Favalli C, Pica F, Sinibaldi Vallebona P, Palamara AT, et al. (2007) Thymosin alpha 1: from bench to bedside. Ann N Y Acad Sci 1112: 225-234.

77. Goldstein AL (2007) History of the discovery of the thymosins. Ann N Y Acad Sci 1112: 1-13

78. Goldstein AL, Goldstein AL (2009) From lab to bedside: emerging clinical applications of thymosin alpha 1. Expert Opin Biol Ther 9: 593-608.

79. Tuthill C, Rios I, McBeath R (2010) Thymosin alpha 1: past clinical experience and future promise. Ann N Y Acad Sci 1194: 130-135.

80. Wolf E, Milazzo S, Boehm K, Zwahlen M, Horneber M (2011) Thymic peptides for treatment of cancer patients. Cochrane Database Syst Rev : CD003993.

81. Lin HY (2004) [Sepsis: challenge and intervention strategy]. Zhongguo Wei Zhong Bing Ji Jiu Yi Xue 16: 325-327.

82. Hotchkiss RS, Karl IE (2003) The pathophysiology and treatment of sepsis. N Engl J Med 348: 138-150.

83. Monneret G, Lepape A, Venet F (2011) A dynamic view of mHLA-DR expression in management of severe septic patients. Crit Care 15: 198.
84. Wu J, Zhou L, Liu J, Ma G, Kou Q, et al. (2013) The efficacy of thymosin alpha 1 for severe sepsis (ETASS): a multicenter, single-blind, randomized and controlled trial. Crit Care 17: R8.

85. Chen J (2007) [Effects of thymosin-alpha1 on cell immunity function in patients with septic shock]. Zhongguo Wei Zhong Bing Ji Jiu Yi Xue 19: 153-155.

86. Zhao M-Y, Cao Y, Fei D, et al. (2007) Influence of thymosin a1 on the cellula immune function in patients with severe sepsis. Chin J Crit Care Med 27: 206208.

87. Li YN, Zhou LX, Qiang XH, Yu TO, Mao KJ, et al. (2009) [Effect of continuous blood purification and thymosin alpha1 on the cellular immunity in patients with severe sepsis: a prospective, randomized, controlled clinical trial]. Zhongguo Wei Zhong Bing Ji Jiu Yi Xue 21: 139-142.

88. Wang X, Li W, Niu C, Pan L, Li N, et al. (2010) Thymosin alpha 1 is associated with improved cellular immunity and reduced infection rate in severe acute pancreatitis patients in a double-blind randomized control study. Inflammation DOI 10.1007/s10753-010-9224-1.

89. Lin HY (2007) Cooperative Group of immunomodulatory Therapy of Sepsis [Clinical trial with a new immunomodulatory strategy: treatment of severe sepsis with Ulinastatin and Maipuxin]. Zhonghua Yi Xue Za Zhi 87: 451-457.

90. Zhang Y, Chen H, Li YM, Zheng SS, Chen YG, et al. (2008) Thymosin alpha1and ulinastatin-based immunomodulatory strategy for sepsis arising from intraabdominal infection due to carbapenem-resistant bacteria. J Infect Dis 198 : 723-730.

91. Li Yumin, Chen Hao, Li Xun, Zhou Wence, He Minyan, et al. (2009) A new immunomodulatory therapy for severe sepsis: Ulinastatin Plus Thymosin \{alpha\} 1. J Intensive Care Med 24: 47-53.

92. Chen H, He MY, Li YM (2009) Treatment of patients with severe sepsis using ulinastatin and thymosin alpha1: a prospective, randomized, controlled pilot study. Chin Med J (Engl) 122: 883-888.

93. Huang SW, Chen J, Ouyang B, Yang CH, Chen MY, et al. (2009) Immunotherapy improves immune homeostasis and increases survival rate of septic patients. Chin J Traumatol 12: 344-349.

94. Aversa F, Terenzi A, Tabilio A, et al. (2005) Full haplotype-mismatched hematopoietic stem-cell transplantation: a phase II study in patients with acute leukemia at high risk of relapse. J Clin Oncol 23:3447-3454

95. Perruccio K, Bonifazi P, Topini F, Tosti A, Bozza S, et al. (2010) Thymosin alpha1 to harness immunity to pathogens after haploidentical hematopoietic transplantation. Ann N Y Acad Sci 1194: 153-161.

96. Romani L, Aversa F, Garaci E, Velardi A (2012) Thymosin alpha 1 improves immune reconstitution in hematopoietic transplantation. Ann NY Acad Sci 1269-1270: 83-84

97. Li C, Wang C-H, Meng Q-H, Ye S-L, Wang X-J, et al. (2007) Effect of the thymosin alpha 1 on immune function in aged chronic obstructive pulmonary disease during acute period. Chin Hosp Pharm J 27: 637-639.

98. Zheng BX, Cheng DY, Xu G, Fan LL, Yang Y, et al. (2008) [The prophylactic effect of thymosin alpha 1 on the acute exacerbation of chronic obstructive pulmonary disease]. Sichuan Da Xue Xue Bao Yi Xue Ban 39: 588-590.

99. Wheeler AP, Bernard GR (2007) Acute lung injury and the acute respiratory distress syndrome: a clinical review. Lancet 369: 1553-1564.

100.Sun Q, Liu ZH, Chen J, Ji S, Tang Z, et al. (2006) An aggressive systematic strategy for acute respiratory distress syndrome caused by severe pneumonia after renal transplantation. Transpl Int 19: 110-116.

101.Ji SM, Li LS, Sun QQ, Chen JS, Sha GZ, et al. (2007) Immunoregulation of thymosin alpha 1 treatment of cytomegalovirus infection accompanied with acute respiratory distress syndrome after renal transplantation. Transplant Proc 39: 115-119.

102. Huang DP, Yang M, Peng WP, Chen XS, Chen ZQ (2006) [Prevention and management of lung infections with thymosin alpha1 in critical patients with tracheotomy]. Nan Fang Yi Ke Da Xue Xue Bao 26: 128-129.

103. Li P, Xu L-H, Zhang Q, et al. (2007) Treatment of drug-resistant Pseudomonas auroginosa pneumonia in elderly patients by using thymosin alpha 1 with sulperazone. Chin J Nosocomial 17: 1271-1273.

104. Gao ZC, Zhu JH, Sun Y, Ding XL, Ma JS, et al. (2003) [Clinical investigation of outbreak of nosocomial severe acute respiratory syndrome]. Zhongguo Wei Zhong Bing Ji Jiu Yi Xue 15: 332-335. 
Citation: Tuthill CW, King RS (2013) Thymosin Apha 1 - A Peptide Immune Modulator with a Broad Range of Clinical Applications. Clin Exp Pharmacol 3: 133. doi:10.4172/2161-1459.1000133

Page 15 of 17

105. Han Y, Zhang X, Ji W, Li Z, Mu J, et al. (2004) Experience of successful recovery of one case of an elderly severe SARS patient. Chin Crit Care Med 16: 58.

106. Lu P, Yang G, Yu W, Jiang X, Zhu W, et al. (2004) Imaging follow up of SARS patients complicated with pulmonary fibrosis. Chin J Med Imaging Technol 20: 1901-1903.

107. Yang G, Zhou B, Chen X, Lu P, Jiang X, et al. (2006) Thymoson alpha 1's effect on cellular mediated immune function of a patient with severe highly pathogenic avian influenza of H5N1 strain.

108. Gerin JL, Korba BE, Cote PJ, Tennant BC (1992) A preliminary report of a controlled study of thymosin alpha 1 in the woodchuck model of hepadnavirus infection. In: Block T, ed. Innovations in Antiviral Development and the Detection of Virus Infection. Philadelphia, Pa: Jefferson Medical, 121-123.

109. Tennant BC, Korba BE, Baldwin BH, Goddard LA, Hornbuckle WE, et al. (1993) Treatment of chronic woodchuck hepatitis virus infection with thymosin alpha-1 (TA1). Antiviral Res 20: 163.

110. Chan HL, Tang JL, Sung JY (2001) Thymosin a1 for the treatment of chronic hepatitis $B$ virus (HBV) infection: a meta-analysis. Digestive Disease Week 2001, Atlanta, GA.

111. Mutchnick MG, Lindsay KL, Schiff ER, Cummings GD, Appelman HD, et al. (1999) Thymosin alpha1 treatment of chronic hepatitis B: results of a phase III multicentre, randomized, double-blind and placebo-controlled study. J Viral Hepat 6: 397-403.

112. Andreone P, Cursaro C, Gramenzi A, Zavagliz C, Rezakovic I, et al. (1996) A randomized controlled trial of thymosin-alpha1 versus interferon alfa treatment in patients with hepatitis $B$ e antigen antibody--and hepatitis B virus DNApositive chronic hepatitis B. Hepatology 24: 774-777.

113. Chien RN, Liaw YF, Chen TC, Yeh CT, Sheen IS (1998) Efficacy of thymosin alpha1 in patients with chronic hepatitis B: a randomized, controlled trial. Hepatology 27: 1383-1387.

114. Yang YF, Zhao W, Zhong YD, Yang YJ, Shen L, et al. (2008) Comparison of the efficacy of thymosin alpha-1 and interferon alpha in the treatment of chronic hepatitis B: a meta-analysis. Antiviral Res 77: 136-141.

115. You J, Zhuang L, Cheng H-Y, Yan S-M, Qiao Y-W, et al. (2005) A randomized controlled, clinical study of thymosin alpha 1 versus interferon alpha in Chinese patients with chronic hepatitis B lacking hepatitis B envelope antigen. J Chinese Med Assoc 68: 65-72.

116. You J, Zhuang L, Cheng H-Y, Yan S-M, Yu L, et al. (2006) Efficacy of thymosin alpha 1 and interferon alpha in treatment of chronic viral hepatitis $B$ : a randomized controlled trial. World J Gastroenterol 12: 6715-6721.

117. Zhuang L, You J, Tang BZ, Din SY, Yan KH, et al. (2001) Prelminary results of thymosin alpha 1 versus interferon alpha treatment in patients wih $\mathrm{HBeAg}$ negative and serum HBV DNA positive chronic hepatitis B. World J Gastroenterol 7: 407-410.

118. Chow W, $\mathrm{Ng} \mathrm{K}$, Mesenas S, Law N, Ng H (1998) The interim results of thymosin alpha 1 in a randomized controlled study in the treatment of chronic hepatitis B patients: Singapore experience. Hepatology 28: 586A

119. Zavaglia C, Severini R, Tinelli C, Franzone JS, Airoldi A, et al. (2000) A randomized, controlled study of thymosin-alpha1 therapy in patients with antiHBe, HBV-DNA-positive chronic hepatitis B. Dig Dis Sci 45: 690-696.

120. lino S, Toyota J, Kumada H, Kiyosawa K, Kakumu S, et al. (2005) The efficacy and safety of thymosin alpha- 1 in Japanese patients with chronic hepatitis B; results from a randomized clinical trial. J Viral Hepat 12: 300-306.

121. Rasi G, Mutchnick MG, Di Virgilio D, Sinibaldi-Vallebona $P$, Pierimarchi $P$ et al. (1996) Combination low-dose lymphoblastoid interferon and thymosin alpha 1 therapy in the treatment of chronic hepatitis B. J Viral Hepat 3: 191 196.

122. Saruc M, Yuceyar H, Kucukmetin N, Demir MA, Kandiloglu AR (2002) Combination thymosin-alpha 1 and interferon-alpha $2 \mathrm{~b}$ in the treatment of anti-HBe-positive chronic hepatitis B in Turkey. Hepatogastroenterology 49: 798-802.

123. Saruc M, Ozden N, Turkel N, Ayhan S, Hock LM, et al. (2003) Long-term outcomes of thymosin-alpha 1 and interferon alpha-2b combination therapy in patients with hepatitis $B$ e antigen $(\mathrm{HBeAg})$ negative chronic hepatitis $B$. J Pharm Sci 92: 1386-1395.
124. Lu Z, Gao J, Yao G, Ji Y, Zhang Q, et al. (1997) A comparative trial of thymosin alone and thymosin plus alpha interferon in the treatment of Chinese patients with chronic hepatitis $B(\mathrm{CHB})$. Hepatology 26: 426A.

125. Lim SG, Wai CT, Lee YM, Dan YY, Sutedja DS, et al. (2006) A randomized placebo-controlled trial of thymosin-alpha1 and lymphoblastoid interferon for HBeAg-positive chronic hepatitis B. Antivir Ther 11: 245-253.

126. Lau G, Yuen S, Kwok A, Lai S, Lim W, et al. (1999) Six-months follow-up on a 26 week trial of thymosin a 1 plus famciclovir in the treatment of Chinese immune tolerant adult patients with chronic hepatitis B. Gastroenterol 116 : A339.

127. Suoglu OD, Elkabes B, Sokucu S, Saner G (2001) Thymosin alpha and lamivudine combination therapy in pediatric patients with chronic hepatitis $B$ infection unresponsive to previous treatments: a pilot study. Gut 49.

128. Lee HW, Lee JI, Um SH, Ahn SH, Chang HY, et al. (2008) Combination therapy of thymosin alpha-1 and lamivudine for $\mathrm{HBeAg}$ positive chronic hepatitis $\mathrm{B}$ : A prospective randomized, comparative pilot study. J Gastroenterol Hepatol 23 729-735

129. Leung $Y$, So T (1998) Treatment of chronic hepatitis B using thymosin alpha and a combination of two nucleoside analogues, lamivudine and famciclovir. Hepatology 28: 216A.

130. Hanafiah M, Groeger J, Flaxman AD, Wiersma ST (2013) Global epidemiology of hepatitis $\mathrm{C}$ virus infection: new estimates of age-specific antibody to $\mathrm{HCV}$ seroprevalence. Hepatology 57: 1333-1342.

131. Rasi G, DiVirgilio D, Mutchnick MG, Colella F, Sinibaldi-Vallebona P, et al (1996) Combination thymosin alpha 1 and lymphoblastoid interferon treatment in chronic hepatitis C. Gut 39: 679-683.

132. Moscarella S, Buzzelli G, Monti M, et al. (1997) Treatment with interferonalpha and thymosin alpha 1 of naive patients affected by chronic hepatitis $\mathrm{C}$. 4th International Meeting on Hepatitis C Virus and Related Viruses, Kyoto, Japan.

133. Sherman KE, Sjogren M, Creager RL, Damiano MA, Freeman S, et al. (1998) Combination therapy with thymosin alpha1 and interferon for the treatment of chronic hepatitis C infection: a randomized, placebo-controlled double-blind trial. Hepatology 27: 1128-1135.

134. Sherman K, Sherman S (1998) Interferon plus thymosin a-1 treatment of chronic hepatitis $C$ infection: a meta-analysis. In: Schinazi R, Sommadossi J Thomas H, eds. Therapies for Viral Hepatitis. London, England: International Medical Press, 379-383.

135. Poo JL, Sanchez-Avila F, Kershenobich D, Garcia-Samper X, Gongora J, et al. (2004) Triple combination of thymalfasin, peginterferon alfa-2a and ribavirin in patients with chronic hepatitis $\mathrm{C}$ who have failed prior interferon and ribavirin treatment: 24-week interim results of a pilot study. J Gastroenterol Hepato 19: S79-81.

136. Poo JL, Sánchez Avila F, Kershenobich D, García Samper X, Torress-lbarra $R$, et al. (2008) Efficacy of triple therapy with thymalfasin, peginterferon alpha$2 \mathrm{a}$, and ribavirin for the treatment of hispanic chronic HCV nonresponders. Ann Hepatol 7: 369-375.

137. Ciancio A, Andreone P, Kaiser S, Mangia A, Milella M, et al. (2012) Thymosin alpha-1 with peginterferon alfa-2a/ribavirin for chronic hepatitis $C$ no responsive to IFN/ribavirin: an adjuvant role? J Viral Hepat 19 Suppl 1: 52-59.

138. Garaci E, Rocchi G, Perroni L, et al. (1992) Combined therapy with zidovudinethymosin alpha 1 -alpha interferon in the treatment of HIV-infected patients. Second International Symposium on Combination Therapies, Sicily, Italy.

139. Garaci E, Milanese G, Vella S, et al. (1998) A randomized controlled study for the evaluation of the activity of a triple combination of zidovudine, thymosin alpha 1 and interferon alpha in HIV-infected individuals with CD4 counts between 200 and 500 cells/mm3. Antiviral Ther 3: 103-111.

140. Rosenberg SA, Mulé JJ, Spiess PJ, Reichert CM, Schwarz SL (1985) Regression of established pulmonary metastases and subcutaneous tumor mediated by the systemic administration of high-dose recombinant interleukin 2. J Exp Med 161: 1169-1188.

141. Balch CM, Reintgen DS, Kirkwood JM, Houghton A, Peters L, et al. (1997) Cutaneous Melanoma. In: DeVita V, Hellman S, Rosenberg S, eds. Cancer: Principles and Practice of Oncology. 5th ed. Philadelphia, Pa: Lippincot Williams \& Wilkins, 1947-1994.

142. Richards JM, Gale D, Mehta N, Lestingi T (1999) Combination of chemotherapy 
Citation: Tuthill CW, King RS (2013) Thymosin Apha 1 - A Peptide Immune Modulator with a Broad Range of Clinical Applications. Clin Exp Pharmacol 3: 133. doi:10.4172/2161-1459.1000133

Page 16 of 17

with interleukin-2 and interferon alfa for the treatment of metastatic melanoma. J Clin Oncol 17: 651-657.

143. Venook AP, Papandreou C, Furuse J, de Guevara LL (2010) The incidence and epidemiology of hepatocellular carcinoma: a global and regional perspective. Oncologist 15 Suppl 4: 5-13.

144. Stefanini GF, Foschi FG, Castelli E, et al. (1998) Alpha-1-thymosin and transcatheter arterial chemoembolization in hepatocellular carcinoma patients: a preliminary experience. Hepatogastroenterol 45: 209-215.

145.Zhang WJ (2000) Transcatheter arterial chemotherapy and embolization plus thymosin alpha 1 for treatment of hepatocellular carcinoma. J Gastroentero Hepatol 15: A401.

146. Li ZS (2001) HCC patients treated with TACE combined with thymalfasin: one year follow up. Shanghai International Oncology Conference.

147. Cheng S, Wu M, Chen H, Shen F, Yang J, et al. (2004). Combination transcatheter hepatic arterial chemoembolization with thymosin alpha 1 on recurrence prevention of hepatocellular carcinoma. Hepato-gastroenterology 51: $1445-1447$.

148. Cheng SQ, Wu MC, Chen H, Shen F, Yang JH, et al. (2004) [Transcatheter hepatic arterial chemoembolization and thymosin alpha1 in postoperative treatment of hepatocellular carcinoma]. Zhonghua Zhong Liu Za Zhi 26: 305307.

149. Cheng SQ, Wu MC, Chen H, Shen F, Yang JH, et al. (2005) [Anti-viral therapy using lamivudine and thymosin is helpful to prevent recurrence in hepatocellular carcinoma with coexisting active hepatitis B]. Zhonghua Zhong Liu Za Zhi 27: 114-116.

150. Cheng S, Ding G, Shi J, Guo W, Zhao Y, et al. (2005) Role of antivirus therapy in treatment of hepatocellular carcinoma with chronic hepatitis B infection. Chinese-German J Clin Oncol 4: 330-333

151. Shuqun C, Mengchao W, Han C, Feng S, Jiahe Y, et al. (2006) Antivira therapy using lamivudine and thymosin alpha1 for hepatocellular carcinoma coexisting with chronic hepatitis B infection. Hepatogastroenterology 53: 249252.

152. Cheng SQ, Wu MC, Chen H, Shen F, Yang JH, et al. (2005) [Hepatocellular carcinoma with tumor thrombi in the portal vein. A comparison of therapeutic effects by different treatments]. Zhonghua Zhong Liu Za Zhi 27: 183-185.

153. Gish RG, Gordon SC, Nelson D, Rustgi V, Rios I (2009) A randomized controlled trial of thymalfasin plus transarterial chemoembolization for unresectable hepatocellular carcinoma. Hepatol Int 3: 480-489.

154.Schulof RS, Lloyd MJ, Cleary PA, Palaszynski SR, Mai DA, et al. (1985) A randomized trial to evaluate the immunorestorative properties of synthetic thymosin-alpha 1 in patients with lung cancer. J Biol Response Mod 4: 147158.

155. Garaci E, Lopez M, Bonsignore G, Della Giulia M, D'Aprile M, et al. (1995) Sequential chemoimmunotherapy for advanced non-small cell lung cancer using cisplatin, etoposide, thymosin-alpha 1 and interferon-alpha 2a. Eur $J$ Cancer 31A: 2403-2405

156. Salvati F, Rasi G, Portalone L, Antilli A, Garaci E (1996) Combined treatment with thymosin-alpha1 and low-dose interferon-alpha after ifosfamide in nonsmall cell lung cancer: a phase-II controlled trial. Anticancer Res 16: 10011004

157. Ma D, Lin D, Mei L, Ping Y (2006) The use of thymosin alpha 1 in advanced non-small cell lung cancer treatment. Shangdong Pharmaceutical 46: 77

158. Hou X (2007) Clinical effects of advanced patients with non-small cell lung cancer treatment by thymosin alpha 1 combined with NP regimens. Journal of Bethune Military Medical College 5: 272-274.

159.Shi X, Ding Q, Yang Q (2007) Effects of domestic thymosin alpha 1 in combination with chemotherapy in treatment of advanced non-small cell lung cancer. Practical J Cardiac, Cerebral, Pneumal, Vascular Dis. 15: 764-766.

160.Sun X, Gao F, Liu X, Li G (2009) The influence of thymosin alpha 1 on cellular immune function during chemotherapy for non-small cell lung cancer patients. Shangdong Medical Journal 49: 83-83.

161. Liang G, Zhou Z, Yang J (2010) Combination of thymosin alpha 1 with lowdose gemcitabine for advanced on-small cell lung cancer in elderly patients. $J$ Practical Oncol. 25: 470-473.

162. Jiang J, Wang X, Tian J, Li L, Lin Q (2011) Thymosin plus cisplatin with vinorelbine or gemcitabine for non-small cell lung cancer: a systematic review and meta-analysis of randomized controlled trials. Thoracic Cancer 2: 213 220.

163. Bhatia S, Tykodi SS, Thompson JA (2009) Treatment of metastatic melanoma: an overview. Oncology (Williston Park) 23: 488-496.

164. Lucas R, McMichael T, Smith W, Armstrong B (2006) Solar ultraviolet radiation: global burden of disease from solar ultraviolet radiation. Environmental Burden of Disease Series 13, World Health Organization.

165. Lopez M, Carpano S, Cavaliere R, Di Lauro L, Ameglio F, et al. (1994) Biochemotherapy with thymosin alpha 1, interleukin-2 and dacarbazine in patients with metastatic melanoma: clinical and immunological effects. Ann Oncol 5: 741-746.

166. Rasi G, Terzoli E, Izzo F, Pierimarchi P, Ranuzzi M, et al. (2000) Combined treatment with thymosin-alpha1 and low dose interferon-alpha after dacarbazine in advanced melanoma. Melanoma Res 10: 189-192.

167. Maio M, Mackiewicz A, Testori A, Trefzer U, Ferraresi V, et al. (2010) Large randomized study of thymosin alpha 1 , interferon alfa, or both in combination with dacarbazine in patients with metastatic melanoma. J Clin Oncol 28: 1780 1787 .

168. Chen J, Huang FL, Zheng XL, Chen LX, Qin SK, et al. (2000) Thymosin alpha 1 positively alters quality of life in chemotherapy treated patients. Annual ASCO Proceedings.

169. Luna GC, Naval GR, Gorospe AD, Daep M, Jurilla M, et al. (2000) The effect of thymosin alpha on the cellular immune profile of cancer patients receiving chemotherapy. Jl Immunother 23: 588

170.Ni Q, Fu D, Yu X, Xu J, Hua Y, et al. (2001) Efficacy of thymalfasin on cellula immune function and chemotherapy induced toxicity in pancreatic cancer 37th Annual ASCO Proceedings 20: 2630.

171. Yang YM, Lu XY, Huang WD, Shen MY (2003) [Effect of thymosin alpha 1 on cellular immune function in elderly patients with malignant tumor]. Zhejiang Da Xue Xue Bao Yi Xue Ban 32: 339-341.

172. Wang Y, Zhen S, Qin J, Zhang Y, Yang W, et al (2010) Curative effect analysis of thymosin alpha 1 in treating senile patients with advanced malignant cancer. Journal of Military Surgeon in Southwest China 12: 821-822.

173. Liu X, An T (2003) Thymalfasin for the protection of chemotherapy-induced neurotoxicity: a pilot study. Proceedings of ASCO 22: 3153.

174. An TT, Liu XY, Fang J, Wu MN (2004) [Primary assessment of treatment effect of thymosin alpha1 on chemotherapy-induced neurotoxicity]. Ai Zheng 23: $1428-1430$

175.Zhang Q, Tang D, Zhao H (2010) Immunological therapies can relieve aromatase inhibitor-related joint symptoms in breast cancer survivors. Am J Clin Oncol 33: 557-560.

176. Makinodan T, Peterson WJ (1962) Relative antibody-forming capacity of spleen cells as a function of age. Proc Natl Acad Sci U S A 48: 234-238.

177.Wade AW, Szewczuk MR (1984) Aging, idiotype repertoire shifts, and compartmentalization of the mucosal-associated lymphoid system. Adv Immunol 36: 143-188.

178. Ershler WB, Moore AL, Hacker MP, Ninomiya J, Naylor P, et al. (1984 Specific antibody synthesis in vitro. II. Age-associated thymosin enhancement of antitetanus antibody synthesis. Immunopharmacology 8: 69-77.

179. Bramwell SP, Tsakiris DJ, Briggs JD, Follett EA, Stewart J, et al. (1985) Dinitrochlorobenzene skin testing predicts response to hepatitis $B$ vaccine in dialysis patients. Lancet 1: 1412-1415.

180.Dammin GJ, Couch NP, Murray JE (1957) Prolonged survival of skin homografts in uremic patients. Ann N Y Acad Sci 64: 967-976.

181.Lawrence HS (1965) Uremia--Nature's Immunosuppressive Device. Ann Intern Med 62: 166-170.

182. Revie D, Shen S, Ordonez J, et al. (1985) T-cell subsets and status of hepatitis $B$ surface antigen and antibody in end-stage renal disease patients. Kidney Int 27: 150

183. Sanders CV Jr, Luby JP, Sanford JP, Hull AR (1971) Suppression of interferon response in lymphocytes from patients with uremia. J Lab Clin Med 77: 768776.

184. Stevens CE, Alter HJ, Taylor PE, Zang EA, Harley EJ, et al. (1984) Hepatitis 
Citation: Tuthill CW, King RS (2013) Thymosin Apha 1 - A Peptide Immune Modulator with a Broad Range of Clinical Applications. Clin Exp Pharmacol 3: 133. doi:10.4172/2161-1459.1000133

$B$ vaccine in patients receiving hemodialysis. Immunogenicity and efficacy. N Engl J Med 311: 496-501.

185. Grob PJ, Binswanger U, Zaruba K, Joller-Jemelka HI, Schmid M, et al. (1983) Immunogenicity of a hepatitis $B$ subunit vaccine in hemodialysis and in renal transplant recipients. Antiviral Res 3: 43-52.

186. Crosnier J, Jungers $P$, Courouc AM, et al. (1981) Randomised placebocontrolled trial of hepatitis $B$ surface antigen vaccine in French haemodialysis units: I, medical staff. Lancet 1: 455-459.

187. Gravenstein S, Ershler WB, Drumaskin S, Schwab R, Weksler ME (1986) Anti-influenza antibody response: augmentation in elderly ?non-responders by thymosin alpha 1 . Gerontologist 26: $150 \mathrm{~A}$.

188. Gravenstein S, Duthie EH, Miller BA, Roecker E, Drinka P, et al. (1989) Augmentation of influenza antibody response in elderly men by thymosin alpha one. A double-blind placebo-controlled clinical study. J Am Geriatr Soc 37: $1-8$

189. McConnell L, Gravenstein S, Roecker E, Spencer S, Simon G, et al. (1989)
Augmentation of influenza antibody levels and reduction in attack rates in elderly subjects by thymosin alpha 1 . Gerentologist $29: 188 \mathrm{~A}$.

190. Shen S, Josselson J, McRoy C, Sadler J, Chretien P (1987) Effect of thymosin alpha 1 on heptavax-B vaccination among hemodialysis patients. Kidney Int 1987: 217.

191. Shen S, Josselson J, McRoy C, Sadler J, Chretien P (1987) Effects of thymosin alpha 1 on peripheral T-cell and Heptavax-B vaccination in previously nonresponsive hemodialysis patients. Hepatology 7: 1120

192. Shen SY, Corteza QB, Josselson J, et al. (1990) Age-dependent enhancement of influenza vaccine responses by thymosin in chronic hemodialysis patients. In: Goldstein AL, ed. Biomedical Advances in Aging. New York, NY: Plenum Press; 1990: 523-530

193. Carraro G, Naso A, Montomoli E, Gasparini R, Camerini R, et al. (2012) Thymosin-alpha 1 (Zadaxin) enhances the immunogenicity of an adjuvated pandemic H1N1v influenza vaccine (Focetria) in hemodialyzed patients: a pilot study. Vaccine 30: 1170-1180. 